\title{
Contribution of IL-1RI Signaling to Protection against Cryptococcus neoformans 52D in a Mouse Model of Infection
}

\author{
Mitra Shourian ${ }^{1,2}$, Ben Ralph ${ }^{3,4}$, Isabelle Angers ${ }^{2,5}$, Donald C. Sheppard ${ }^{3,4,6}$ \\ and Salman T. Qureshi ${ }^{1,2,5,6 *}$
}

\begin{abstract}
${ }^{1}$ Division of Experimental Medicine, McGill University, Montreal, QC, Canada, ${ }^{2}$ Meakins-Christie Laboratories, McGill University, Montreal, QC, Canada, ${ }^{3}$ Program in Infectious Diseases and Immunology in Global Health, Centre for Translational Biology, The Research Institute of the McGill University Health Center (RI-MUHC), Montreal, QC, Canada, ${ }^{4}$ Department of Microbiology and Immunology, McGill University, Montreal, QC, Canada, ${ }^{5}$ Program in Translational Research in Respiratory Diseases, Department of Critical Care, The Research Institute of the McGill University Health Center (RI-MUHC), Montreal, QC, Canada, ${ }^{6}$ Department of Medicine, McGill University, Montreal, QC, Canada
\end{abstract}

\section{OPEN ACCESS}

Edited by: Amariliz Rivera,

New Jersey Medical School,

United States

Reviewed by:

Karen L. Wozniak,

Oklahoma State University,

United States

Michal Adam Olszewski,

University of Michigan,

United States

*Correspondence:

Salman T. Qureshi

salman.qureshi@mcgill.ca

Specialty section:

This article was submitted to

Microbial Immunology,

a section of the journal

Frontiers in Immunology

Received: 25 September 2017 Accepted: 21 December 2017

Published: 19 January 2018

Citation:

Shourian M, Ralph B, Angers I, Sheppard DC and Qureshi ST (2018) Contribution of IL-1RI Signaling to

Protection against Cryptococcus neoformans 52D in a Mouse Model of Infection.

Front. Immunol. 8:1987. doi: 10.3389/fimmu.2017.01987
Interleukin-1 alpha $(\mathrm{IL}-1 \alpha)$ and interleukin-1 beta $(\mathrm{IL}-1 \beta)$ are pro-inflammatory cytokines that are induced after Cryptococcus neoformans infection and activate the interleukin-1 receptor type I (IL-1RI). To establish the role of IL-1RI signaling in protection against cryptococcal infection, we analyzed wild-type (WT) and IL-1RI-deficient (IL-1R| $\left.\left.\right|^{-/-}\right)$mice on the BALB/c background. IL-1R| $\left.\right|^{-/-}$mice had significantly reduced survival compared to WT mice after intratracheal challenge with $C$. neoformans 52D. Microbiological analysis showed a significant increase in the lung and brain fungal burden of $|\mathrm{L}-1 \mathrm{RI}|^{-/}$compared to WT mice beginning at weeks 1 and 4 postinfection, respectively. Histopathology showed that $\mid \mathrm{L}-1 \mathrm{RI}^{-/-}$mice exhibit greater airway epithelial mucus secretion and prominent eosinophilic crystals that were absent in WT mice. Susceptibility of $|\mathrm{L}-1 \mathrm{RI}|^{-/-}$mice was associated with significant induction of a Th2-biased immune response characterized by pulmonary eosinophilia, M2 macrophage polarization, and recruitment of CD4+ $\mathrm{IL}-13^{+}$ T cells. Expression of pro-inflammatory [IL-1 $\alpha, \mathrm{IL}-1 \beta$, TNF $\alpha$, and monocyte chemoattractant protein 1 (MCP-1)], Th1-associated (IFN $\gamma$ ), and Th17-associated (IL-17A) cytokines was significantly reduced in $\mathrm{LL}-1 \mathrm{Rl}^{-/-}$lungs compared to WT. WT mice also had higher expression of KC/CXCL1 and sustained neutrophil recruitment to the lung; however, antibody-mediated depletion of these cells showed that they were dispensable for lung fungal clearance. In conclusion, our data indicate that IL-1RI signaling is required to activate a complex series of innate and adaptive immune responses that collectively enhance host defense and survival after $C$. neoformans 52D infection in BALB/c mice.

Keywords: Cryptococcus neoformans, fungal pneumonia, interleukin-1, interleukin-1 receptor, lung inflammation, cytokines, macrophage polarization, lymphocyte differentiation

\section{INTRODUCTION}

Cryptococcus neoformans is an encapsulated yeast that is estimated to cause approximately 223,000 cases of meningitis each year and is responsible for 15\% of AIDS-related deaths (1). In healthy individuals, inhalation of infectious propagules is usually contained in the lung, but among those with a defective immune response, uncontrolled replication may result in dissemination to other 
parts of the body with a tropism for the brain $(2,3)$. Severe cryptococcal disease occurs primarily in patients with uncontrolled HIV/AIDS and is also found in solid organ transplant recipients, those receiving exogenous immunosuppression, patients with primary or acquired immunodeficiency, and increasingly among immunologically normal hosts (4-7).

The pattern of cytokine expression is a crucial determinant of the pathogenesis of cryptococcal infection (3, 8-11). Th1-type cytokines [interleukin (IL)-12 and IFN $\gamma$ ] promote phagocytosis by dendritic cells (DCs) and polarize macrophages toward a classically activated phenotype (M1), thereby increasing fungal clearance (12-15). On the other hand, Th2-type cytokines (IL4, IL-5, and IL-13) are associated with a significant eosinophil chemotaxis to the lungs and induction of alternatively activated (M2) macrophages that facilitate cryptococcal proliferation and dissemination (16-18). There is some evidence that Th17-type cytokines (IL-17A and IL-23) contribute to protection against infection with wild-type (WT) C. neoformans; however, they appear to be less effective compared to Th1-type cytokines (19-23). Inhibition of IL-17A expression or signaling had no significant effect on M1 macrophage polarization, resolution of infection, or survival in mice infected with C. neoformans H99 that has been engineered to express $\operatorname{IFN} \gamma(24,25)$. Finally, a prospective analysis of HIV-infected humans suggested a potential role for IL-17 in the immunopathogenesis of cryptococcal meningitis; however, further studies are required to confirm this hypothesis (26).

The mechanisms that initiate and regulate the innate immune response against $C$. neoformans infection are not fully understood. The interaction of $C$. neoformans with host cells triggers production of several pro-inflammatory cytokines including TNF $\alpha$, IL-6, and IL-1 (27-30). Both interleukin-1 alpha (IL-1 $\alpha$ ) and interleukin-1 beta (IL-1 $\beta$ ) are induced during cryptococcal infection in vitro $(27,28,31-34)$ and in vivo (35-40) in a NLRP3-dependent manner, and internalization of opsonized encapsulated cryptococci has been shown to activate the canonical NLRP3-ASC-caspase-1 and non-canonical NLRP3-ASC-caspase-8 inflammasome $(34,41)$. The magnitude of IL-1 expression between inbred mice with different genetic backgrounds has also been associated with natural resistance or susceptibility to progressive cryptococcal infection (35). After intratracheal infection with C. neoformans $52 \mathrm{D}$, the level of IL-1 $\beta$ expression was 11 -fold higher in the lungs of resistant SJL/J inbred mice compared to the susceptible C57BL/6 inbred strain. A subsequent analysis of WT and interleukin-1 receptor (IL-1R)-deficient mice on the C57BL/ 6 genetic background did not identify significant differences in survival or fungal dissemination after intranasal infection with $C$. neoformans H99; however, at day 12 postinfection, the IL-1 $\mathrm{R}^{-/-}$mice had a modest elevation of lung fungal burden (37).

Given the essential role for cytokine-mediated inflammation and the evidence for IL- $1 \alpha$ and IL- $1 \beta$ induction in response to C. neoformans, we hypothesized that the contribution of IL-1Rdependent signaling to host defense may have been underestimated by infection of WT and IL-1R $\mathrm{R}^{-1-}$ mice on the susceptible C57BL/6 genetic background with a highly virulent C. neoformans strain. To test this hypothesis, we performed intratracheal inoculation of inbred $\mathrm{BALB} / \mathrm{c}$ mice and $\mathrm{IL}-1 \mathrm{R}^{-/-}$mice on the same genetic background with C. neoformans 52D and analyzed fungal burden and immune responses at serial time points. This approach was chosen to model the process of natural infection in a relatively resistant host with a moderately virulent cryptococcal strain. Our findings demonstrate that IL-1RI ${ }^{-/}$mice had a significantly higher fungal burden in the lungs and brains as well as a significantly higher mortality compared to BALB/c mice. In IL-1RI ${ }^{-/-}$mice, $C$. neoformans $52 \mathrm{D}$ infection was associated with heightened lung eosinophilia, elevated airway mucus secretion, and a greater percentage of M2 macrophages and CD4 ${ }^{+}$Th2 cells along with significantly fewer lung neutrophils, DCs, Th1, and Th17 cells. Taken together, this study shows that IL-1R-dependent signaling contributes to protection against C. neoformans 52D infection in $\mathrm{BALB} / \mathrm{c}$ mice by triggering a complex innate and adaptive immune response and raises the possibility that modulation of this signaling axis could be a potential therapeutic strategy.

\section{MATERIALS AND METHODS}

\section{Mice}

Inbred BALB/c mice were purchased from Charles River and maintained in our facility. IL-1RI $\mathrm{RI}^{-/}$mice were purchased from Jackson Labs and backcrossed to BALB/c for 10 generations. Mice were provided with sterile food and water and cared for according to the Canadian Council on Animal Care guidelines. All experiments were performed using 7-to 9-week-old male and female mice. Mice were humanely euthanized with $\mathrm{CO}_{2}$ upon completion of experiments, and every effort was made to minimize suffering. All experimental protocols were reviewed and approved by the McGill University Animal Care Committee.

\section{Cryptococcus neoformans}

Cryptococcus neoformans 52D (ATCC 24067) was grown and maintained on Sabouraud dextrose agar (SDA; BD, Becton Dickinson and Company). To prepare an infectious dose, a single colony was suspended in Sabouraud dextrose broth (BD) and grown to early stationary phase $(48 \mathrm{~h})$ at room temperature on a rotator. The stationary phase culture was then washed with sterile phosphate-buffered saline (PBS), counted on a hemocytometer, and diluted to $2 \times 10^{5} \mathrm{CFU} / \mathrm{ml}$ in sterile PBS. The fungal concentration of the experimental dose was confirmed by plating a dilution of the inoculum on SDA and counting the CFU after $72 \mathrm{~h}$ of incubation at room temperature.

\section{Intratracheal Infection with C. neoformans}

For intratracheal administration of C. neoformans, mice were anesthetized with $150 \mathrm{mg} / \mathrm{kg}$ of ketamine (Ayerst Veterinary Laboratories) and $10 \mathrm{mg} / \mathrm{kg}$ of xylazine (Bayer) intraperitoneally. A small skin incision was made below the jaw along the trachea, and the underlying glands and muscle were separated. Infection was performed by intratracheal injection of $10^{4} \mathrm{C}$. neoformans in $50 \mu \mathrm{l}$ PBS through a 22-gauge catheter via a 1-ml tuberculin syringe. The incision was closed using the 9-mm EZ clip wound closing kit (Stoelting CO), and mice were monitored daily after surgery. 


\section{Tissue Isolation and CFU Assay}

After mice were euthanized with $\mathrm{CO}_{2}$, their lungs, spleen, and brain were excised and placed in sterile, ice-cold PBS. Tissues were then homogenized using a glass tube and pestle attached to a mechanical tissue homogenizer (Glas- $\mathrm{Col}$ ) and plated at various dilutions on SDA. Plates were incubated at $37^{\circ} \mathrm{C}$ for $72 \mathrm{~h}$, and $\mathrm{CFU}$ were counted. For survival analyses, mice were inoculated as stated above and monitored twice daily for up to 110 days postinfection.

\section{Histopathological Analysis}

After euthanasia, lungs were perfused with ice-cold PBS via the right ventricle of the heart. Using $10 \%$ buffered formalin acetate (Fisher Scientific), the lungs were inflated to a pressure of $25 \mathrm{~cm}$ $\mathrm{H}_{2} \mathrm{O}$ and fixed overnight. Subsequently, lungs were embedded in paraffin, sectioned at $5 \mu \mathrm{m}$, and stained with hematoxylin-eosin (H\&E), periodic acid-Schiff (PAS), or mucicarmine reagents at the Histology Facility of the Goodman Cancer Research Centre (McGill University). Representative photographs of lung sections were taken using a BX51 microscope (Olympus), QICAM Fast 1394 digital charge-coupled device camera (QImaging), and Image-Pro Plus software version 7.0.1.658 (Media Cybernetics).

\section{Flow Cytometry}

Lungs were excised using sterile technique and placed in RPMI (Gibco, Invitrogen) supplemented with $10 \%$ fetal bovine serum (Wisent). Subsequently lungs were minced using surgical blades and incubated with $1 \mathrm{mg} / \mathrm{ml}$ collagenase (Sigma) at $37^{\circ} \mathrm{C}$ for $1 \mathrm{~h}$. After incubation, lung pieces were passed through a 16-gauge needle and filtered through a $70-\mu \mathrm{m}$ cell strainer (BD). Red blood cells were removed using ACK lysis buffer, cells were counted with a hemacytometer using trypan blue dye, and $5 \times 10^{6}$ cells in $100 \mu \mathrm{l} \mathrm{FACS}$ buffer/well were dispensed in 96-well plates. Fc receptors were blocked with the addition of unlabeled anti-CD16/32 antibodies [93; eBioscience (eBio)], and single-cell suspensions were stained with the following fluorescence-conjugated anti-mouse monoclonal antibodies purchased from eBio, BD, and BioLegend: CD45 (30-F11), B220 (RA3-6B2), CD3e (145-2C11), CD4 (GK1.5), CD8 (53-6.7), CD49b (DX5), $\gamma \delta$ TCR (GL3), CD11b (M1/70), CD11c (N418), MHCII (M5/114.15.2), Ly6G (1A8), CD86 (GL1), CD80 (1610A1), CD64 (X54-5/7.1), CD24 (M1/69), SiglecF (E50-2440), CD103 (2E7), Ly6C (HK1.4), and CD206 (C068C2). Non-viable cells were excluded using a fixable viability dye reagent (eBio). Lineage negative cells $\left(\mathrm{Lin}^{-}\right)$were defined as $\mathrm{CD} 45^{+}$cells that did not express any other surface markers in this panel. Data were acquired using a LSRFortessa flow cytometer (BD) and analyzed using Flow Jo software. The absolute number of leukocytes was determined by multiplying the percentage of $\mathrm{CD} 45^{+}$cells by the total number of counted cells.

\section{Intracellular Staining}

Lungs were processed as described above, and $5 \times 10^{6}$ cells/well were dispensed in 96-well plates. For cytokine analysis, cells were stimulated for $4 \mathrm{~h}$ with phorbol 12-myristate 13-acetate (PMA) and calcium ionophore (ionomycin) in the presence of brefeldin
A (GolgiPlug) for the final $3 \mathrm{~h}$. Cells were then washed, blocked with anti-CD16/32 antibodies, and stained with the surface antibodies. Cells were then fixed, permeabilized, and stained with IL-13 (eBio13A), IFN $\gamma$ (XMG1.2), and IL-17A (17B7). Intracellular staining for Nos2 (CXNFT) was done as described for cytokines without PMA and ionomycin stimulation. Data were acquired using a LSRFortessa flow cytometer with gating determined by fluorescence-minus-one controls and analyzed using FlowJo software.

\section{Total Lung Cytokine and Chemokine Production}

Mice were euthanized and lungs flushed with $10 \mathrm{ml}$ of ice-cold PBS. Whole lungs were homogenized in $2 \mathrm{ml}$ PBS with Halt protease and phosphatase inhibitor cocktail (Fisher Scientific) using a sterilized glass tube and pestle attached to a mechanical tissue homogenizer (Glas-Col) and spun at 12,000 rpm for $20 \mathrm{~min}$. Supernatants were collected, and aliquots were stored at $-80^{\circ} \mathrm{C}$ for further analysis. The following cytokines and chemokines in whole-lung protein samples were analyzed using DuoSet enzyme-linked immunosorbent assay kits (R\&D Systems): TNF $\alpha$ (DY410), IL-6 (DY406), IL-1 $\beta$ (DY401), IL-1 $\alpha$ (DY400), monocyte chemoattractant protein 1 (MCP-1; MJE00), IL-12/IL-23P40 (DY2398), IFN $\gamma$ (DY485), CXCL1/KC (DY453), IL-17A (DY421), and IL-13 (DY413).

\section{Neutrophil Depletion}

$\mathrm{BALB} / \mathrm{c}$ mice received an intratracheal inoculum of $1 \times 10^{4} \mathrm{CFU}$ of $C$. neoformans strain 52D. Mice were treated with $100 \mu \mathrm{l}$ of PBS or $200 \mu \mathrm{g}$ of anti-1A8 antibody (Bio X Cell) in a volume of $100 \mu \mathrm{l}, 1$ day before infection and daily during the study. At day 12 postinfection, lungs were excised, and fungal burden was analyzed.

\section{Statistical Analysis}

To test the significance of single comparisons, an unpaired Student's $t$-test was applied with a threshold $P \leq 0.05$. For all experiments, the mean and SEM is shown. Survival curves were analyzed by the log-rank test. All statistical analysis was performed with GraphPad Prism software version 6 (GraphPad Software Inc.).

\section{RESULTS}

\section{IL-1RI ${ }^{-1-}$ Mice Have Impaired Survival and an Increased Fungal Burden in the Lung, Brain, and Spleen following C. neoformans 52D Infection}

To investigate the role of IL-1RI-mediated signaling after C. neoformans 52D infection, we constructed IL-1RI ${ }^{-1-}$ mice on the BALB/c background by repeated backcrossing. We challenged mice with $C$. neoformans 52D and measured the survival rate and tissue fungal burden. No deaths were observed in WT 
mice; however, IL-1RI ${ }^{-/-}$mice started to die at 40 days postinfection and had a $73 \%$ mortality rate at 100 days postinfection (Figure 1A). Microbiological analysis also showed a significant increase of fungal burden in IL-1RI-l- mice compared to the WT strain at all time points tested (Figure 1B). Importantly, a significant difference in lung fungal burden was observed at 7 days postinfection, suggesting that the IL-1RI signaling affects the initial host response to $C$. neoformans infection. At 35 days postinfection, there was almost a 20 -fold increase of lung CFU in the IL-1RI'-l- compared to the WT strain. Analysis of the spleen showed a trend toward higher CFU in the IL-1RI ${ }^{-/-}$mice compared to the WT strain that reached statistical significance at day 14 postinfection (Figure 1C). Analysis of the brain showed comparable CFU in both strains at 14 days postinfection; however, at 35 days postinfection, all of the WT mice had cleared the infection, while 10 of $16(62 \%)$ of IL-1RI ${ }^{-/-}$mice still had detectable fungal growth (Figure 1D). Taken together, these data establish a role for IL-1R-mediated signaling in controlling fungal growth in the lungs and brain, limiting organ dissemination, and increasing survival after C. neoformans 52D infection.

\section{An Altered Pattern of Pulmonary Inflammation Is Present in IL-1RI ${ }^{-/-}$Lungs following C. neoformans 52D Infection}

The significant differences in survival and fungal burden between WT and IL-1RI ${ }^{-/}$mice prompted us to investigate the effect of IL-1RI signaling on lung pathology after infection with C. neoformans 52D. Histopathological analysis was conducted at 35 days postinfection to correspond with the greatest difference in fungal burden prior to the onset of mortality (Figures 2A-C). $\mathrm{H} \& \mathrm{E}$ staining revealed that WT mice displayed abundant lung leukocyte infiltration that was almost absent in the IL-1RI ${ }^{-/-}$ strain. Notably, eosinophilic crystals that have been associated with alternatively activated macrophages in C. neoformans 52D infection were clearly observed in $\mathrm{IL}-1 \mathrm{RI}^{-/-}$lung sections but were absent in the WT. Mucicarmine staining of the cryptococcal cell wall showed that most fungi were located within WT phagocytes with only a few visible extracellular organisms in the parenchyma or airways. In contrast, $\mathrm{IL}_{-1} 1 \mathrm{RI}^{-/-}$sections showed lung parenchyma that was filled with heavily encapsulated extracellular cryptococci. PAS staining clearly revealed mucus
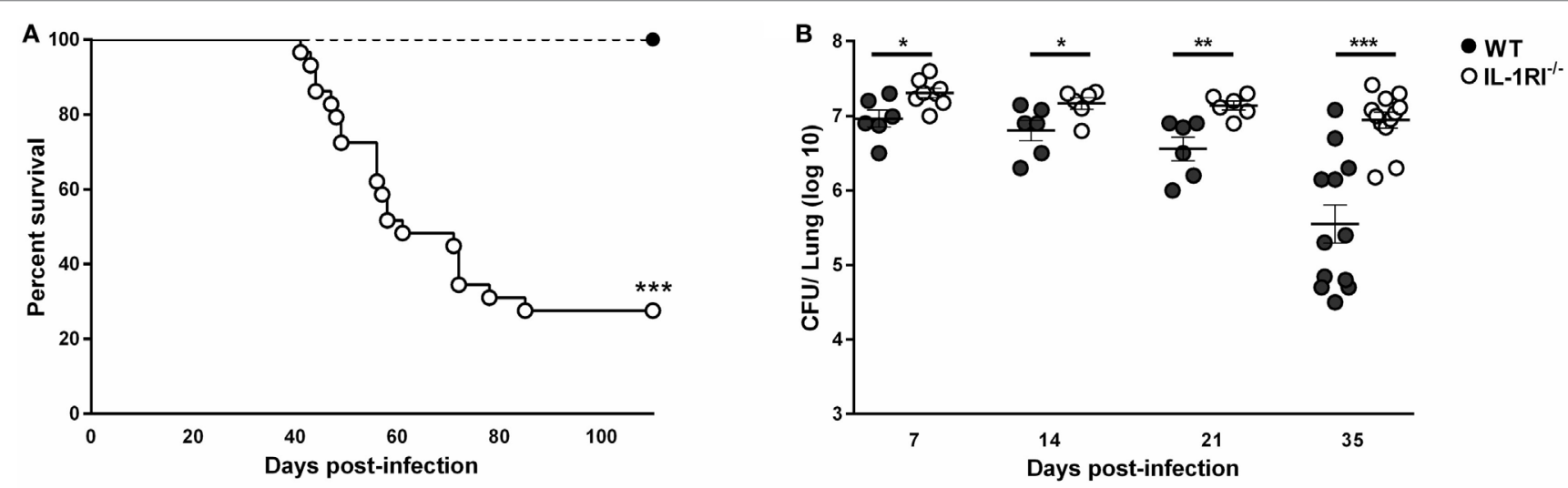

C

D
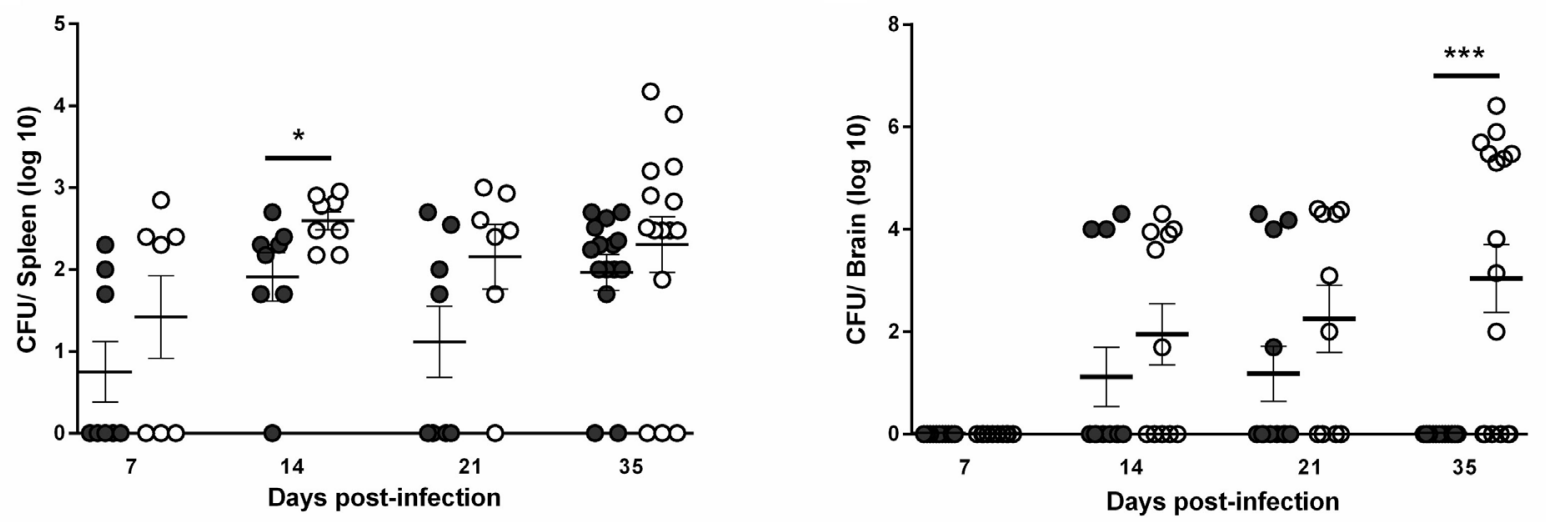

FIGURE 1 | Interleukin-1 receptor type I (IL-1RI) signaling is required for survival and control of fungal burden after infection with Cryptococcus neoformans 52D. Wild-type (WT) and IL-1RI-deficient (IL-1RI- ${ }^{--}$) mice were infected intratracheally with $10^{4} \mathrm{CFU}$ of $\mathrm{C}$. neoformans strain 52D. (A) Mice were observed for up to 110 days for survival analysis ( $n=12$ mice/strain, using a log-rank test). (B-D) Fungal burden in the lung, brain, and spleen at serial time intervals was determined by plating tissue homogenates on Sabouraud dextrose agar. CFU data are shown as mean \pm SEM and representative of two independent experiments $(n=6-15$ mice/strain/time point). ${ }^{*} P \leq 0.05,{ }^{* *} P \leq 0.01$, and ${ }^{* \star *} P \leq 0.001$. 

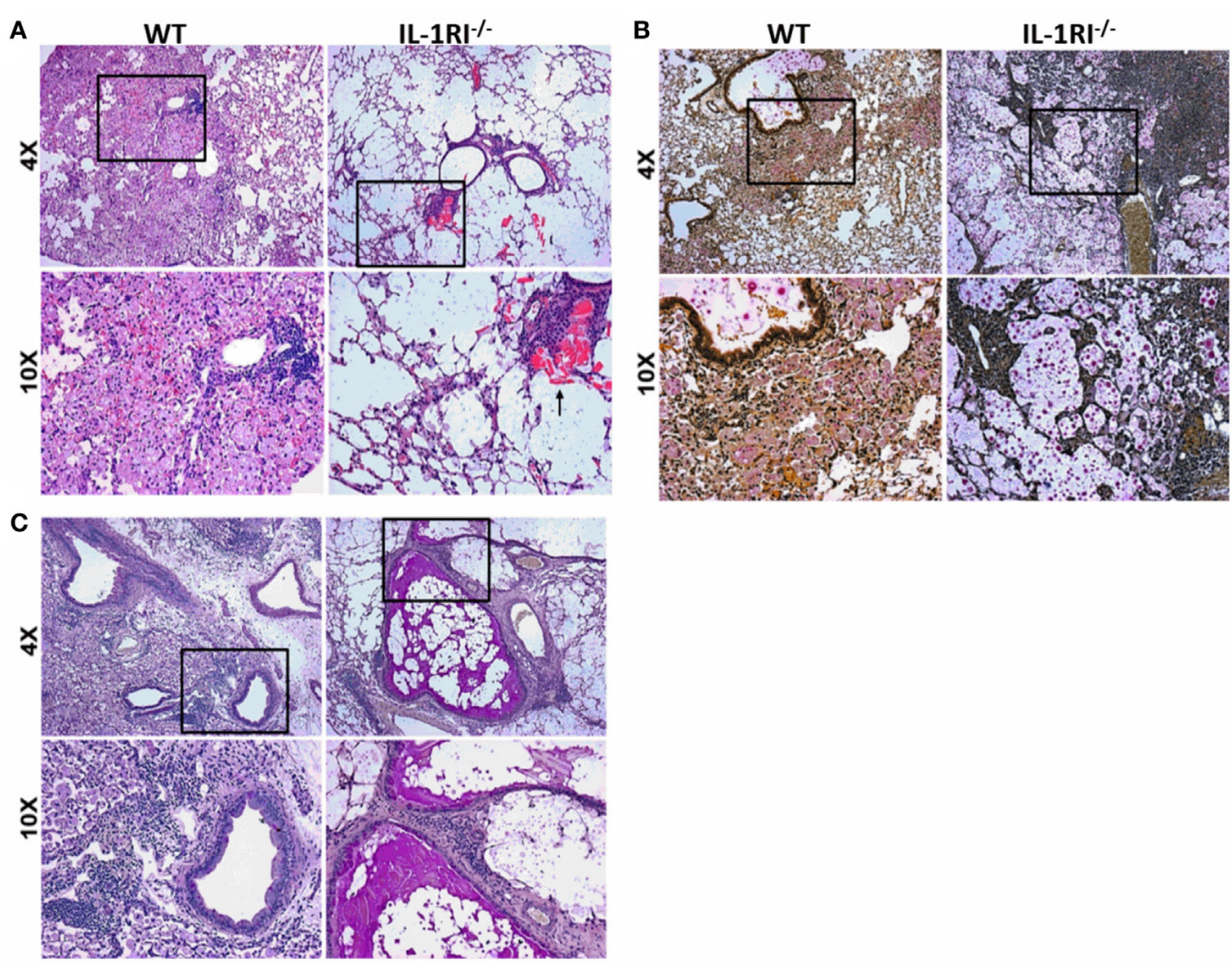

FIGURE 2 | Decreased inflammation in the lungs of interleukin-1 receptor type I-deficient (IL-1R|- ${ }^{--}$) mice following infection with Cryptococcus neoformans 52D. Wild-type (WT) and IL-1R| ${ }^{-/}$mice were infected intratracheally with $10^{4} \mathrm{CFU}$ of C. neoformans 52D. Lungs were harvested at day 35 postinfection; perfused with phosphate-buffered saline; embedded in paraffin; and stained with hematoxylin-eosin (H\&E), mucicarmine, or periodic acid-Schiff (PAS). Representative H\&E images (A) show a significant reduction of inflammation in IL-1R| $\left.\right|^{-/-}$compared to WT mice; the black arrow points to eosinophilic crystals in IL-1 $\mathrm{R}^{-/-}$lung. Mucicarmine staining (B) shows numerous heavily encapsulated extracellular $C$. neoformans in the airspaces of $\mathrm{LL}_{-1 \mathrm{RI}^{-/-}}$mice compared to WT mice. Representative images of lungs stained with PAS (C) show goblet cell hyperplasia and mucus in the airways of infected IL-1RI ${ }^{-/-}$mice compared to WT mice. Each image is representative of 100 fields examined ( $n=4$ mice/strain from two independent experiments).

secretion by airway epithelial cells in IL-1RI-/- mice that was not observed in the airways of WT mice. Taken together, this histopathological analysis confirmed the results of the lung fungal burden studies and demonstrated reduced inflammation with signs of Th2 polarization in IL-1 $\mathrm{RI}^{-/-}$mice compared to the WT strain.

\section{Inflammatory Cytokine and Chemokine Production Is Decreased in the Lungs of IL-1RI ${ }^{-/}-$Mice following C. neoformans 52D Infection}

To determine the effect of IL-1RI signaling on the production of soluble inflammatory mediators, WT and IL-1RI ${ }^{-/-}$mice were infected with $C$. neoformans $52 \mathrm{D}$, and the concentration of pro-inflammatory cytokines (IL- $1 \alpha$, IL-1 $\beta, \mathrm{TNF} \alpha$, and IL-6), chemokines (MCP-1 and KC), Th1-associated cytokines (IFN $\gamma$ and IL-12), and representative Th2-associated (IL-13) and Th17associated (IL-17A) cytokines was measured in whole-lung homogenates at serial time points (Figure 3). No significant differences in the level of these mediators were observed between two strains prior to infection. In WT mice, both IL- $1 \alpha$ and IL- $1 \beta$ were produced in the lungs at day 7 postinfection and continued to increase until day 14 postinfection. Compared to WT, IL-1RI ${ }^{-/-}$ mice had significantly lower production of these two cytokines at day 14 postinfection. The production of TNF $\alpha, M C P-1$, and $\mathrm{KC}$ was significantly higher in WT compared to IL-1RI ${ }^{-/-}$mice at day 14 postinfection. Significantly greater production of IFN $\gamma$ and IL-17A was also observed in the lungs of WT mice compared to $\mathrm{IL}_{-1} 1 \mathrm{RI}^{-/-}$at day 14 postinfection. IL-13 production did not differ between strains at day 7 and day 14 postinfection, although a modest increase was observed in IL-1 $\mathrm{R}^{-/-}$mice compared to WT at day 21 postinfection. In summary, BALB/c mice exhibited significantly greater production of pro-inflammatory, Th1, and Th17 cytokines, as well as chemokines, compared to IL-1RI ${ }^{-1-}$ mice; these findings demonstrate a broad effect of IL-1RI signaling on the lung inflammatory response after C. neoformans 52D infection. 


\section{IL-1RI ${ }^{-/}$Mice Exhibit Reduced Neutrophil and Increased Eosinophil Recruitment to the Lungs following C. neoformans 52D Infection}

To characterize the effect of IL-1RI signaling on the cellular immune response after $C$. neoformans infection, flow cytometry analysis of whole-lung digests was performed on WT and IL-1 $\mathrm{RI}^{-/-}$mice at serial time points postinfection. A comprehensive gating strategy was used for the identification of resident and recruited myeloid cell subsets (Figure 4) (42-44). Prior to infection, no significant difference was observed in the total number of lung leukocytes between the two strains. The total number of $\mathrm{CD} 45^{+}$cells peaked at day 14 in both strains; however, it was significantly higher in WT compared to IL-1RI-l- mice at 14 and 21 days postinfection (Figure 5A). At 7 days postinfection neutrophils (CD $11 c^{-}, C D 11 b^{+}$, and $\left.L y 6 G^{\text {high }}\right)$ were the most frequent leukocyte subset in both strains; however, their percentage and total number was significantly higher in the WT compared to the IL-1RI ${ }^{-/-}$at 14 and 21 days postinfection (Figures 5B,C). Conversely, the percentage and number of lung eosinophils (CD11c ${ }^{-}, \mathrm{CD}_{11 \mathrm{~b}^{+}}$, Siglec $\mathrm{F}^{+}$, and $\mathrm{CD} 24^{+}$)

\section{A}

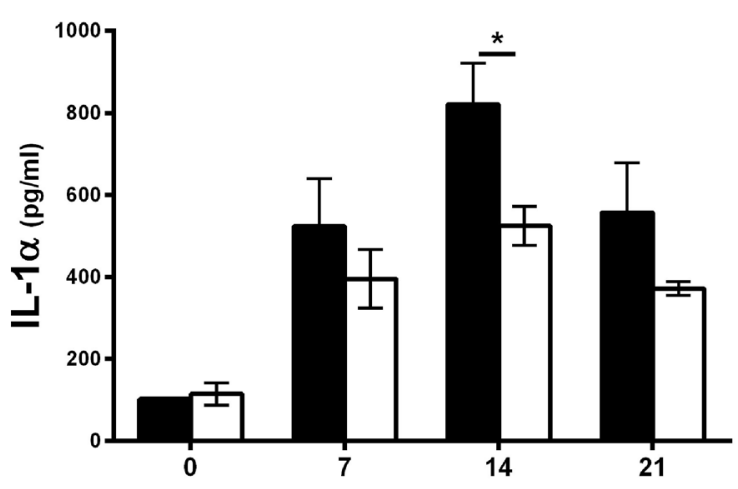

C

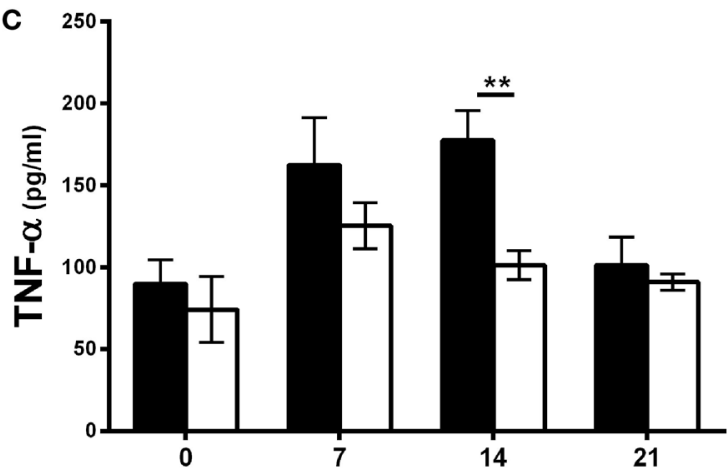

E

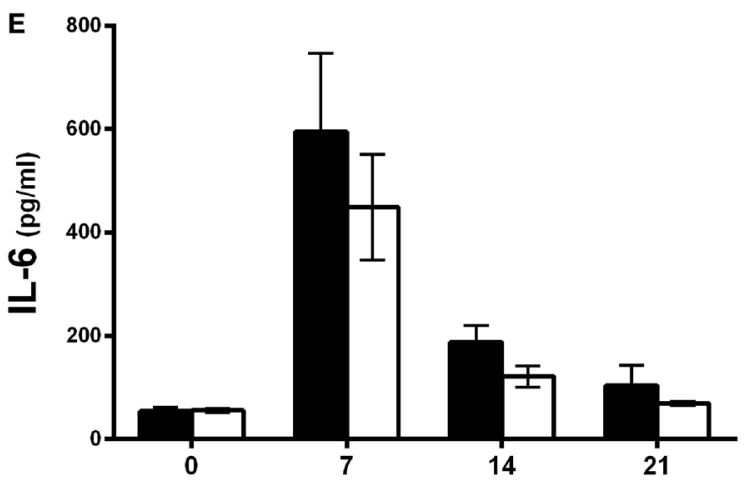

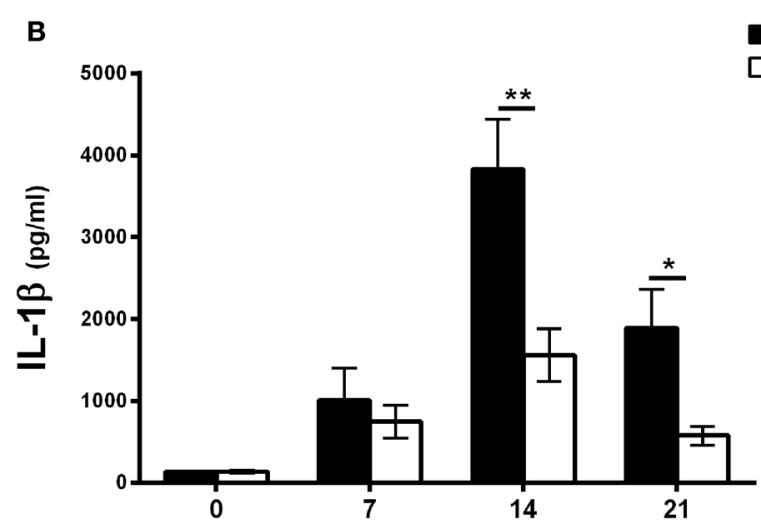
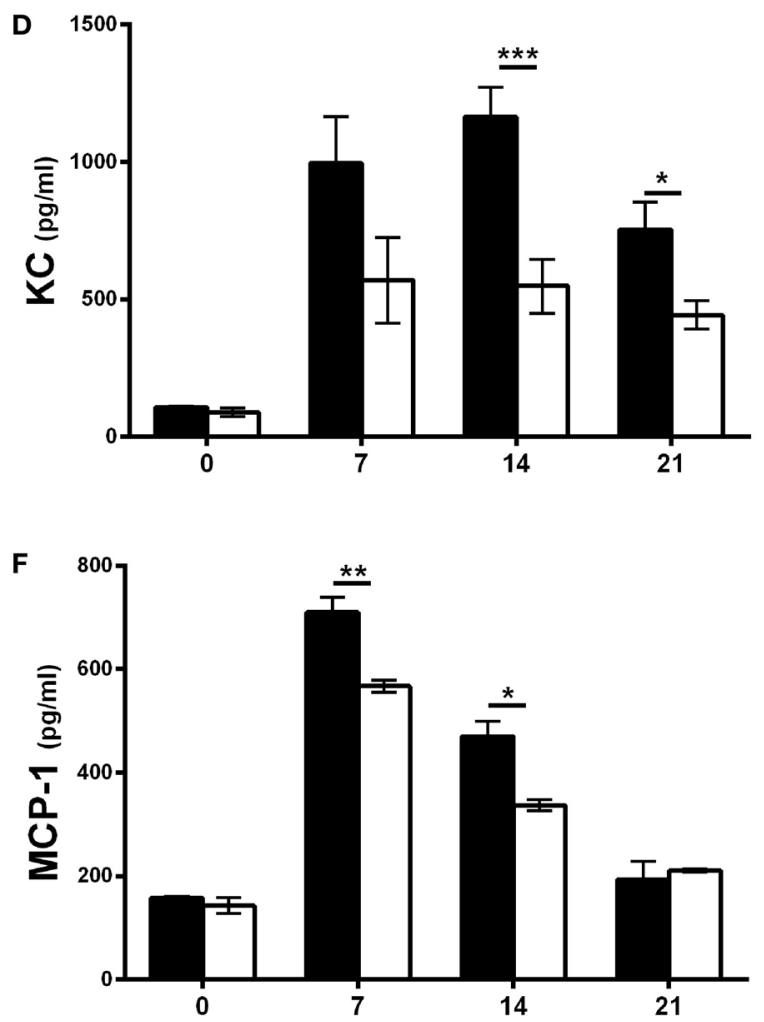

FIGURE 3 | Continued 

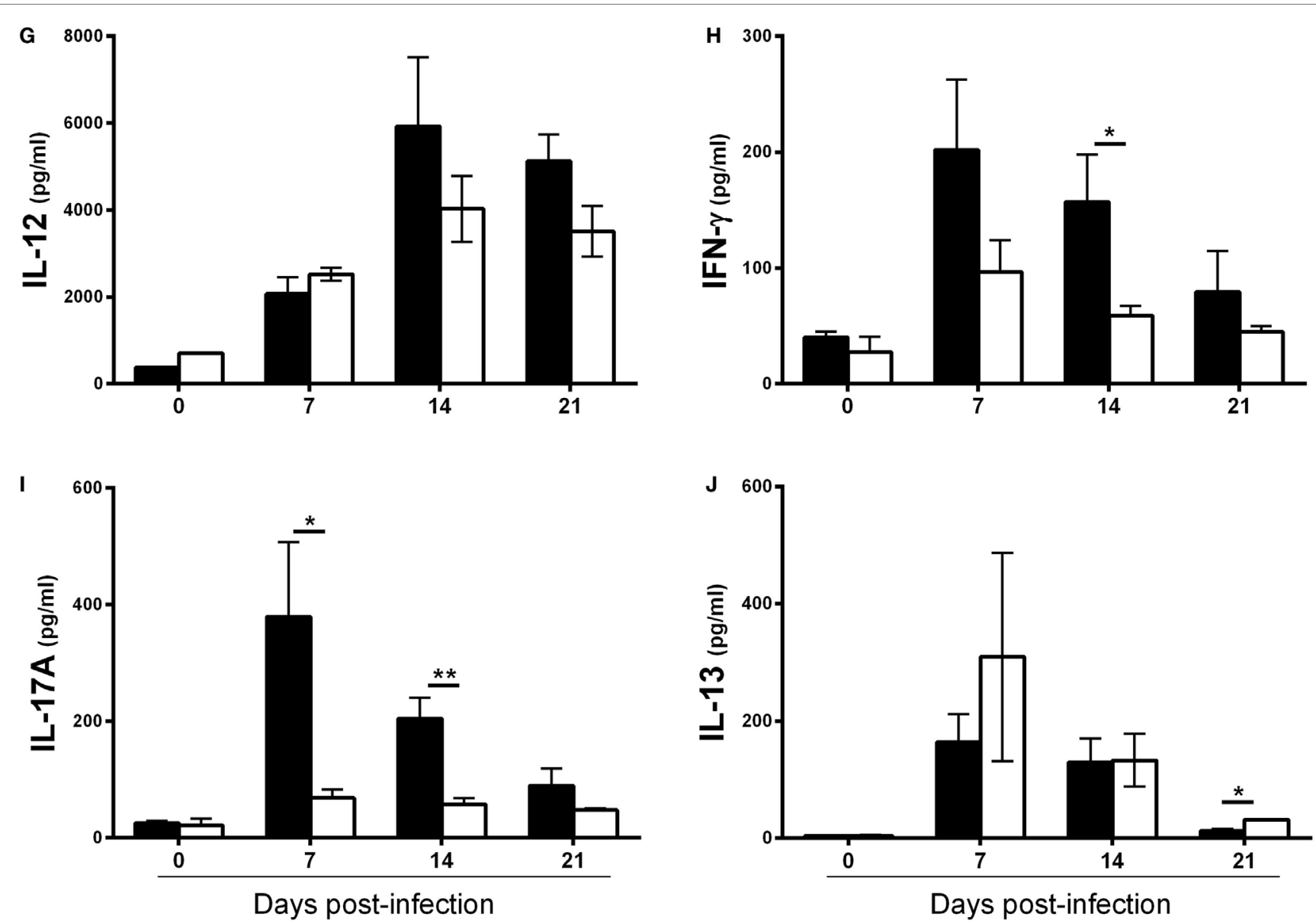

FIGURE 3 | Interleukin-1 receptor type I-deficient (IL-1 $\mathrm{R} \mathrm{I}^{-/-}$) lungs have decreased inflammatory cytokine and chemokine production after Cryptococcus neoformans 52D infection. Whole-lung protein was collected at 0, 7, 14, and 21 days postinfection with $10^{4} \mathrm{CFU}$ of $C$. neoformans 52D. Enzyme-linked immunosorbent assay was performed to determine the level of pro-inflammatory cytokines (A-C, E), chemokines (D, F), and Th1/Th2/Th17-type cytokines (G-J). Data are shown as mean \pm SEM and representative of two independent experiments ( $n=4$ mice/strain/time point). ${ }^{\star} P \leq 0.05$, ${ }^{\star \star} P \leq 0.01$, and ${ }^{\star \star \star} P \leq 0.001$. MCP-1, monocyte chemoattractant protein 1.

was significantly higher in IL-1 $\mathrm{RI}^{-1-}$ mice compared to the WT strain at 14 and 21 days postinfection (Figures 5D,E). These data suggest that IL-1R signaling plays an important role in recruitment of neutrophils during the host response to C. neoformans $52 \mathrm{D}$ infection. In the absence of IL-1R, mice develop significant and sustained lung eosinophilia that is associated with a higher fungal burden.

To evaluate the functional significance of early and sustained neutrophil recruitment to the lungs of BALB/c mice after infection with C. neoformans 52D, the effect of antibody-mediated depletion on tissue fungal burden and lung cell infiltration was characterized. Briefly, WT mice received $200 \mu \mathrm{g}$ of anti-Ly6G antibody (clone 1A8) in a volume of $100 \mu \mathrm{l}$ via intraperitoneal injection $24 \mathrm{~h}$ before infection and daily thereafter. To capture the overall effect of neutrophil depletion during the innate and adaptive phases of immunity, lung fungal burden was determined at 12 days postinfection. Interestingly, this analysis showed that neutrophil-depleted mice had a significantly lower cryptococcal burden in the lungs compared to control mice (Figures 5F-G).

\section{IL-1RI $^{-/-}$Mice Recruit Fewer Monocyte- Derived DC and Macrophages to the Lung following C. neoformans 52D Infection}

Inflammatory monocyte-derived macrophages (ExMs) and DCs are important for protection against $C$. neoformans infection $(45,46)$. We investigated the effect of IL-1RI signaling on the number of resident and monocyte-derived myeloid cells by harvesting lungs at different times postinfection and analyzing cells by flow cytometry. No significant difference in the percentage of pDCs, $\mathrm{CD} 103^{+} \mathrm{DCs}$, and CD $11 \mathrm{~b}^{+} \mathrm{cDC}$ s was observed in the lungs of BALB/c and IL-1R ${ }^{-1-}$ mice after C. neoformans 52D infection; however, at day 21 postinfection, there was a significantly higher percentage and number of AMs in BALB/c compared to IL-1R $\mathrm{R}^{-/-}$ mice (Figures 6 A,B,D). As both monocyte-derived ExMs and 


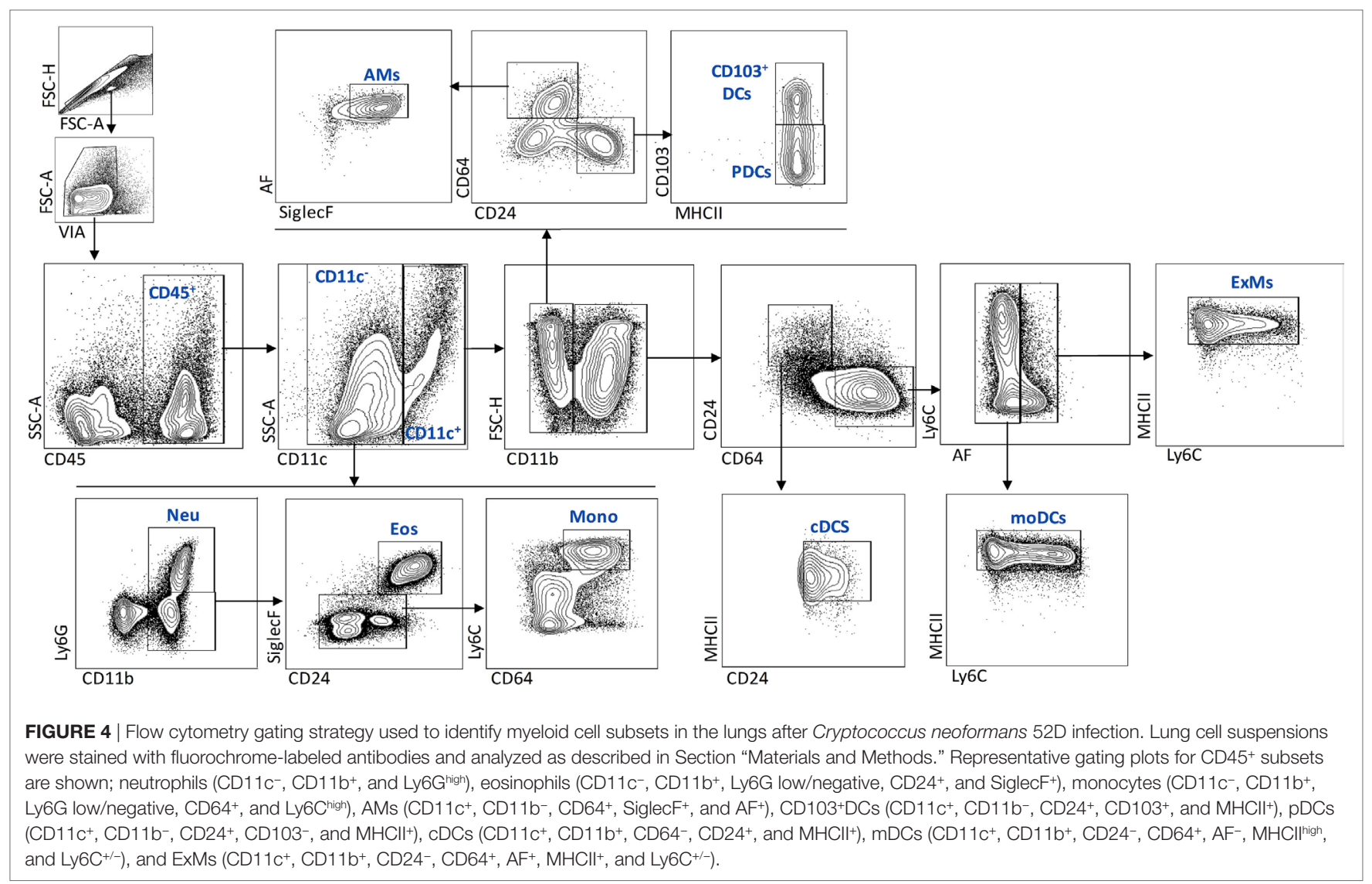

DCs are $\mathrm{CD}_{11 \mathrm{~b}}^{+}, \mathrm{CD} 11 \mathrm{c}^{+}, \mathrm{CD} 24^{-}, \mathrm{MHCII}^{+}$, and $\mathrm{CD} 64^{+}$, we used autofluorescence to distinguish macrophages from DCs $(42,45,47)$ (Figure 4). This analysis showed comparable recruitment of both cell types between the two strains at day 7 postinfection; however, WT mice had a significantly higher number of inflammatory DCs (days 14 and 21) and ExMs (day 21) compared to IL-1RI ${ }^{-/-}$mice (Figures 6C,E).

The macrophage polarization pattern is also important for protection against cryptococcal infection $(8,48)$. Classically activated macrophages (M1) that express high levels of proinflammatory cytokines and costimulatory molecules, produce high levels of reactive nitrogen and oxygen intermediates, and promote strong IL-12-mediated Th1 responses are efficient killers of $C$. neoformans. In contrast, alternatively activated macrophages (M2) that express chitinase-like 3 (Ym1), found in inflammatory zone (FIZZ1), mannose receptor (CD206), and arginase-1 (Arg1), have reduced pro-inflammatory cytokine secretion and are less microbicidal (3, 9, 42, 43, 47, 49-53). As the number of recruited macrophages peaked at day 14 postinfection in both strains, we characterized polarization at this time point using iNOS and CD206 as representative markers for M1 and M2 macrophages, respectively. At 14 days postinfection, the percentage of M1 macrophages was significantly greater in $\mathrm{WT}$ mice compared to IL- $1 \mathrm{R}^{-/-}$mice, while the percentage of M2 macrophages was greater in IL-1 $\mathrm{R}^{-/-}$compared to WT mice (Figures 6F,G). Notably, IL-1RI'-/- macrophages showed greater upregulation of the M2-associated marker CD206 at 14 days postinfection (Figures 6H,I), while WT macrophages displayed higher expression of the M1-associated marker CD80 (43) at 14 and 21 days postinfection (Figures 6J,K). Taken together, these results indicate that IL-1RI signaling has an important role in recruitment of inflammatory DCs and macrophages and increases the ratio of M1/M2-polarized macrophages after C. neoformans 52D infection.

\section{T Cells Are the Predominant Sources of IL-17A and IFN $\gamma$ in WT Lungs Infected with C. neoformans 52D}

To characterize the mechanism of differential IL-17A and IFN $\gamma$ expression between WT and IL-1 $\mathrm{RI}^{-1-}$ lungs, we identified the main sources of these cytokines after C. neoformans 52D infection. Compared to IL-1 $\mathrm{RI}^{-/-}$mice, WT mice showed significantly more IL-17A-producing cells at 7, 14, and 21 days postinfection and a trend toward a higher number of IFN $\gamma$-producing cells at day 21 postinfection (Figures 7A-C). Several immune cell types including $\mathrm{CD}^{+}{ }^{+}$(Th17), CD8 ${ }^{+} \mathrm{T}$ (Tc17) cells, NK cells, iNKT cells, $\gamma \delta$ T cells, B cells, ILCs, DCs, and neutrophils have been shown to produce IL-17 during fungal infection $(25,54-56)$. In our study, at day 7 postinfection, intracellular cytokine staining of WT lymphocytes showed that $\mathrm{CD} 4^{+}$and $\gamma \delta \mathrm{T}$ cells were the most common IL-17A ${ }^{+}$subsets (Figure 7D). A similar pattern was observed at 

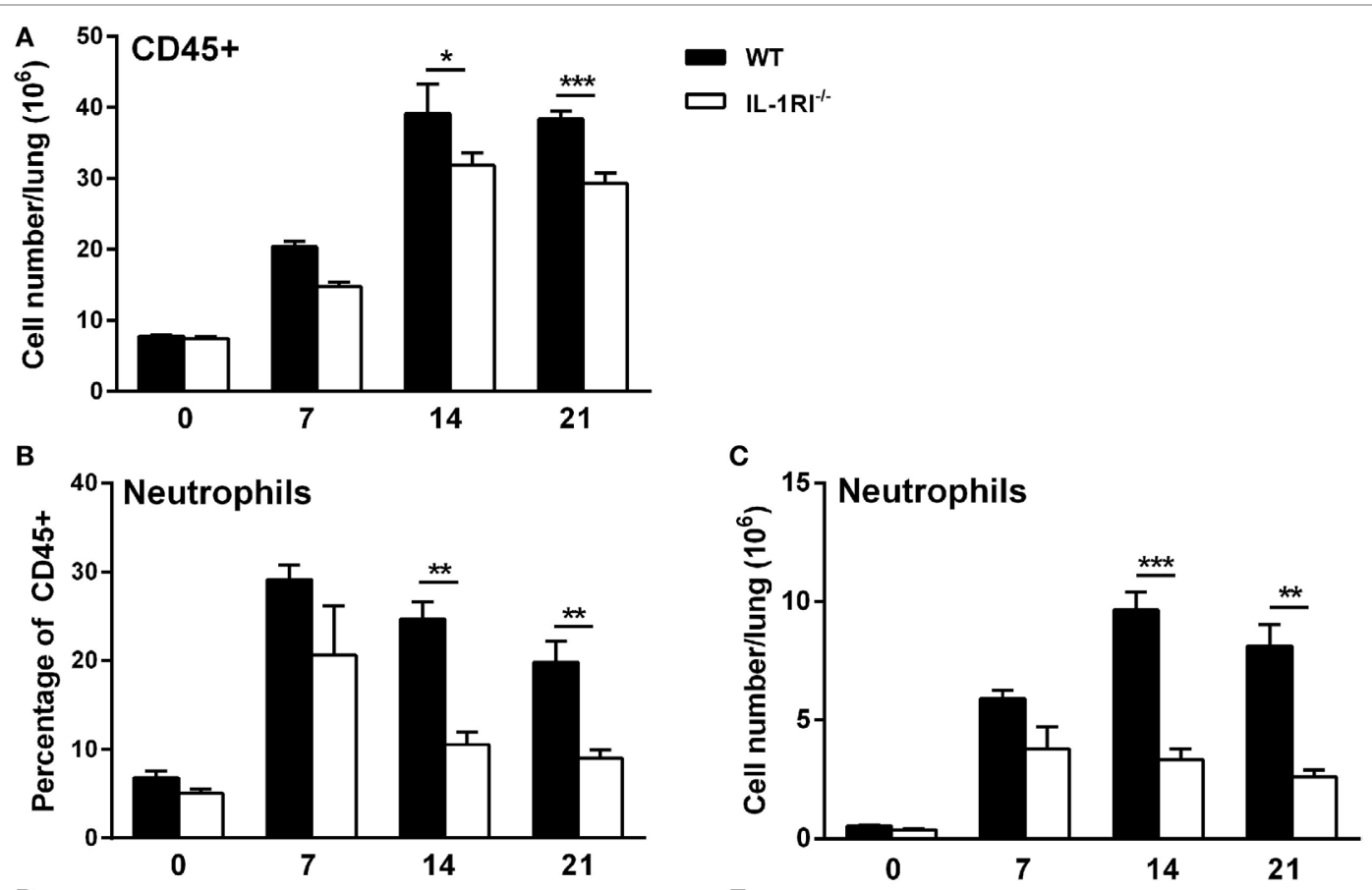

D

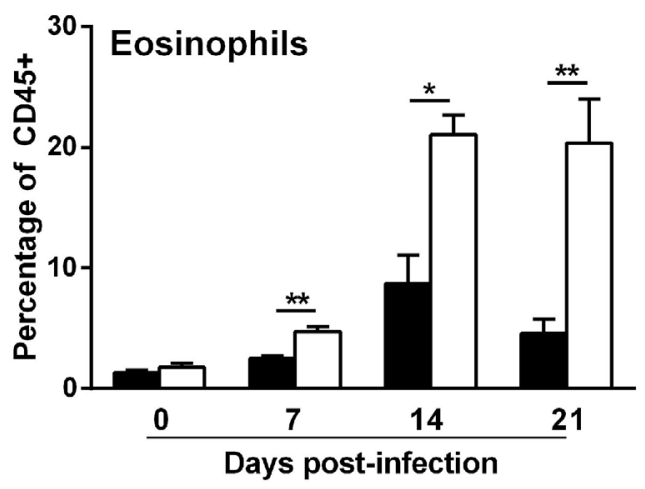

E

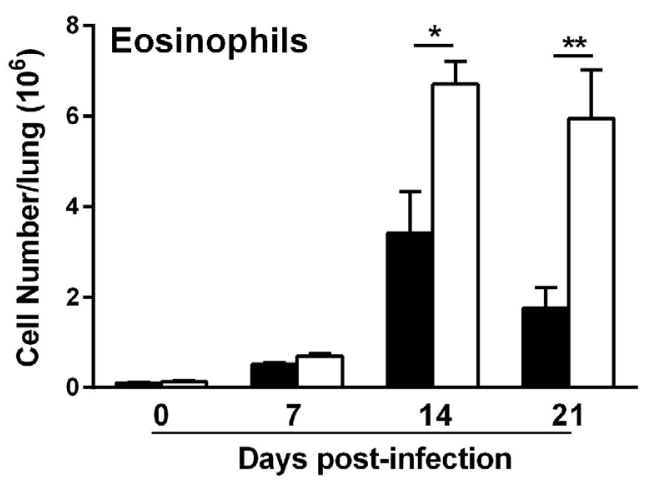

F

G
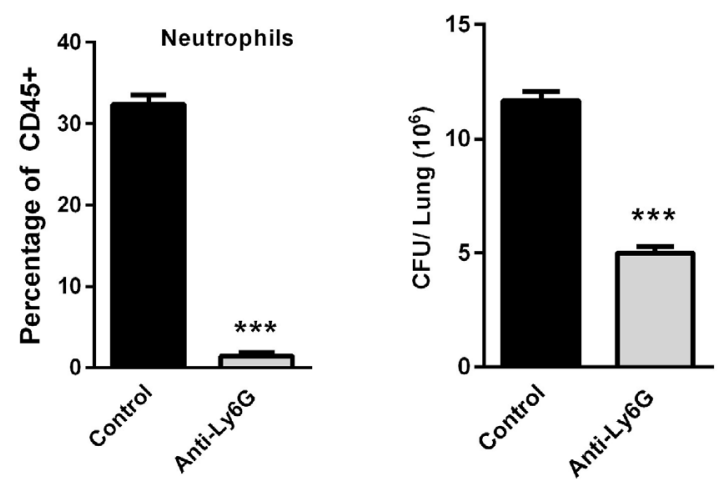

FIGURE 5 | Interleukin-1 receptor type I-deficient (IL-1R| ${ }^{-/-}$) mice have decreased neutrophil and increased eosinophil recruitment to the lungs after Cryptococcus neoformans 52D infection. Lung cell suspensions from uninfected and infected wild-type (WT) and IL-1RI ${ }^{-/-}$mice were stained with fluorochrome-labeled antibodies and analyzed by flow cytometry as described in Section "Materials and Methods." (A) Absolute numbers of total CD45+ cells in the lungs at 0, 7,14 , and 21 days postinfection. (B-E) Percentage and total number of neutrophils and eosinophils at $0,7,14$, and 21 days postinfection. Data are shown as mean \pm SEM and representative of two independent experiments $\left(n=4\right.$ mice/strain/time point). ${ }^{\star} P \leq 0.05,{ }^{* *} P \leq 0.01$, and ${ }^{* \star *} P \leq 0.001$. (F,G) BALB/c mice underwent intratracheal infection with $1 \times 10^{4} \mathrm{CFU}$ of $\mathrm{C}$. neoformans strain 52D. Mice were treated with phosphate-buffered saline or anti-Ly6G antibody 1 day prior to infection and daily during the study. At 12 days postinfection, lungs were excised for analysis of neutrophil recruitment and CFU. (F) The number of neutrophils and (G) fungal burden is shown. Data are pooled from two independent experiments and shown as mean $\pm \mathrm{SEM}\left(n=8\right.$ mice/group). ${ }^{\star \star \star} P \leq 0.001$. 

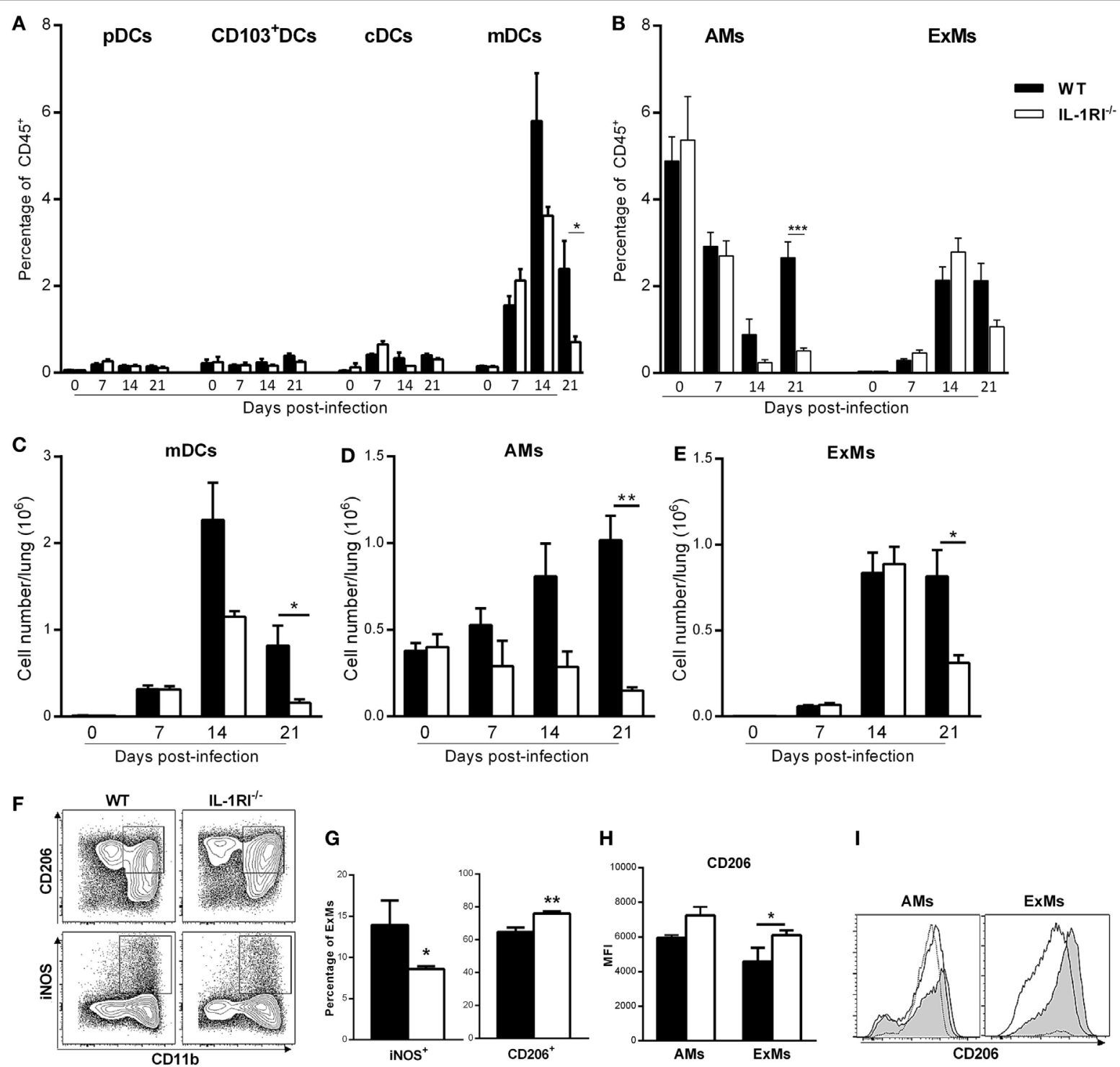

H

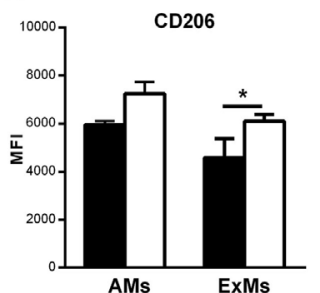

I

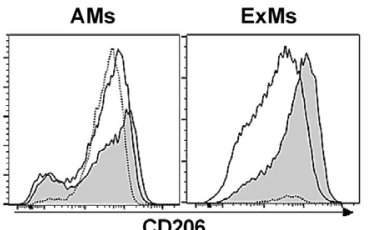

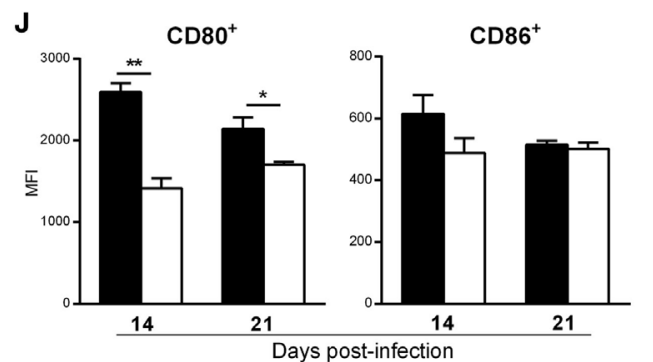

$\mathbf{K}$

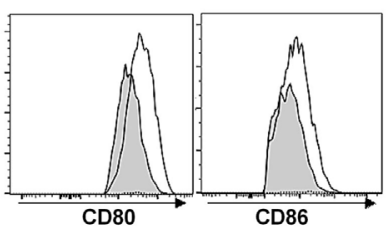

FIGURE 6 | Interleukin-1 receptor type I-deficient (IL-1R $\left.\left.\right|^{-/-}\right)$mice have fewer monocyte-derived dendritic cells (DCs) and macrophages in the lungs after Cryptococcus neoformans 52D infection. Lung cell suspensions from uninfected and infected mice were stained with fluorochrome-labeled antibodies and analyzed by flow cytometry as described in Section "Materials and Methods." (A,B) Percentage of DC and macrophage subsets at 0, 7, 14, and 21 days postinfection. (C-E) Total number of mDCs, AMs, and ExMs at 0, 7, 14, and 21 days postinfection. (F) Representative plots of M1 (CD11 b+, iNOS+) and M2 (CD11b+, CD206+)

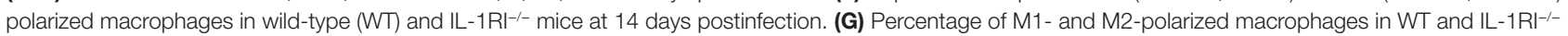
mice at 14 days postinfection. (H) Mean fluorescence intensity (MFI) of CD206 expression on macrophages in WT compared to IL-1RI $\left.\right|^{-/}$mice and (I) Upregulation of CD206 in AMs and ExMs in IL-1R|--- compared to WT mice at 14 days postinfection. (J) MFI and (K) upregulation of CD80- and CD86-positive cells derived from ExMs at 14 days postinfection is shown; $(\mathbf{I}, \mathbf{K}) \mid \mathrm{LL}-1 \mathrm{Rl}^{-/-}$, gray filled lines; WT, white filled solid lines; uninfected mice, dashed lines. Data are shown as mean \pm SEM and representative of two independent experiments $\left(n=4\right.$ mice/strain/time point). ${ }^{*} P \leq 0.05,{ }^{\star \star} P \leq 0.01$, and ${ }^{\star \star \star} P \leq 0.001$. 


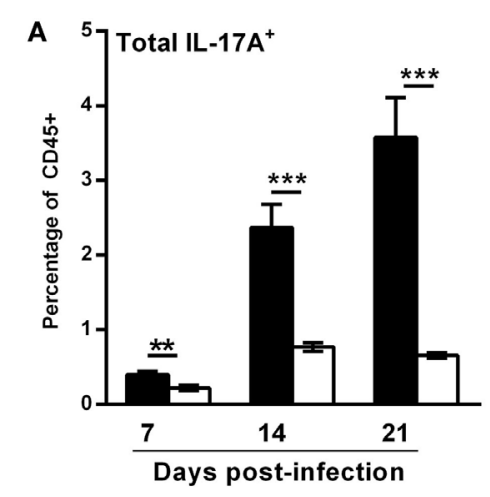

D

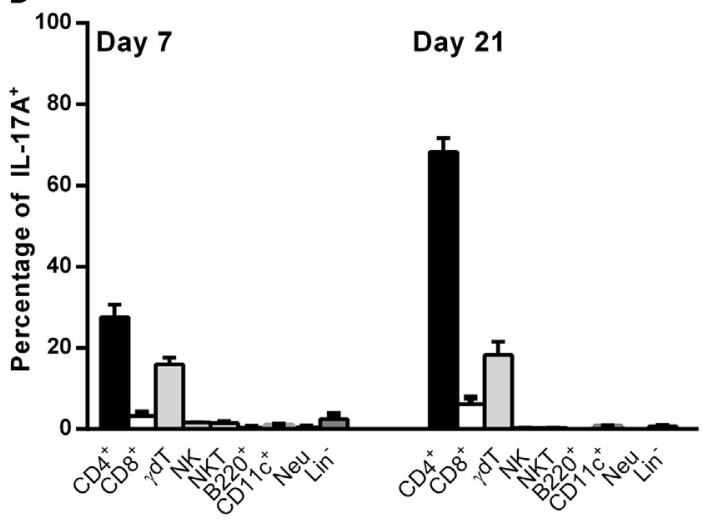

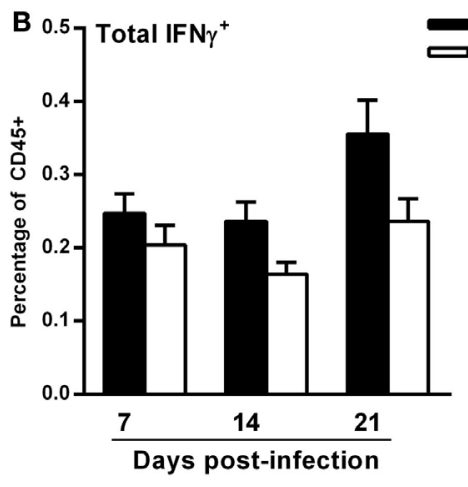

E

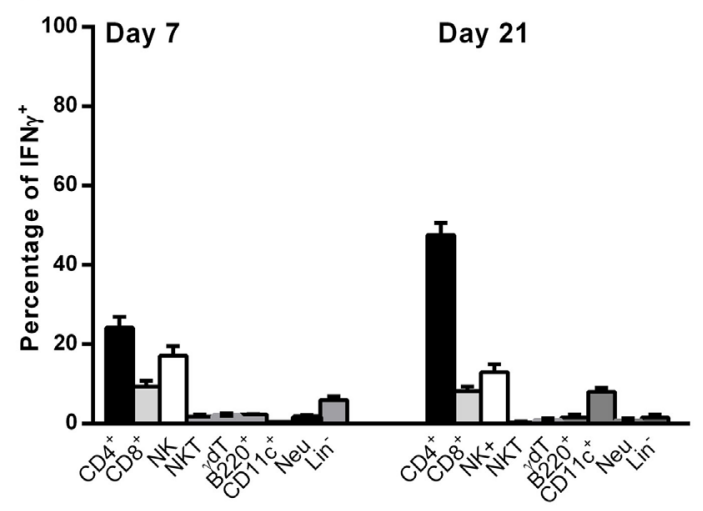

FIGURE 7 | T cells are the predominant sources of interleukin (IL)-17A and IFN $\gamma$ in BALB/c lungs infected with Cryptococcus neoformans 52D. (A) Lung cell suspensions from uninfected and infected mice were harvested and restimulated with phorbol 12-myristate 13-acetate (PMA)-ionomycin followed by intracellular staining for IL-17A and IFN $\gamma$. (A,B) Percentage of total CD45+IFN $\gamma^{+}$and CD45+IL-17A ${ }^{+}$cells at 7, 14, and 21 days postinfection. (C) Representative flow cytometry plots of lung CD45+ cells from individual mice harvested at 21 days postinfection. (D,E) Percentage of IL-17A- and IFN $\gamma$-producing cell types in WT mice at 7 and 21 days postinfection is shown. Data are shown as mean \pm SEM and representative of two independent experiments $\left(n=4\right.$ mice/strain/time point). ${ }^{* \star} P \leq 0.01$ and ${ }^{\star \star \star} P \leq 0.001$.

day 21 postinfection with $\mathrm{CD} 4^{+} \mathrm{T}$ cells and $\gamma \delta \mathrm{T}$ cells accounting for 60 and $20 \%$, respectively, of $\mathrm{IL}_{-17 \mathrm{~A}^{+}}$cells. CD4 ${ }^{+}$and $\mathrm{CD} 8^{+}$ T-cells, NK cells, $\gamma \delta \mathrm{T}$ cells, and neutrophils have been shown to produce IFN $\gamma$ during fungal infection (57-59). In our study, $\mathrm{CD}^{+} \mathrm{T}$ and $\mathrm{NK}$ cells were the predominant IFN $\gamma$-producing subsets at day 7 and day 21 postinfection (Figure 7E).

\section{Effect of IL-1RI Signaling on the Lung Lymphocyte Infiltration following C. neoformans 52D Infection}

As lymphocytes are necessary for effective clearance of $C$. neoformans, we compared the recruitment of $\mathrm{CD} 4^{+}$or $\mathrm{CD} 8^{+} \mathrm{T}$ cells, $\gamma \delta \mathrm{T}$ cells, and $\mathrm{B}$ cells to the lungs of WT and IL-1RI-/- mice at different time points after infection. Flow cytometry analysis showed that WT mice recruit a significantly higher number of $\mathrm{CD}^{+}$cells compared to the IL-1 $\mathrm{RI}^{-/-}$strain at 14 and 21 days postinfection (Figure 8A). Recruitment of $\mathrm{CD}^{+} \mathrm{T}$ cells was comparable between the two strains at all time points, although WT mice showed a trend toward a higher number of $\mathrm{CD}^{+}$ $\mathrm{T}$ cells at day 21 compared to IL-1RI ${ }^{-/-}$mice (Figure 8B). WT mice demonstrated increased recruitment of $\gamma \delta \mathrm{T}$ cells at day 14 and day 21 postinfection compared to uninfected mice; in contrast, there was no significant increase of this cell type in IL-1 $\mathrm{RI}^{-1-}$ mice during infection (Figure 8C). No differences in the number of $\mathrm{B}$ cells recruited to the lungs during infection were observed between the two strains (Figure 8D). Taken together, this analysis demonstrates that IL-1RI signaling selectively regulates $\mathrm{T}$ lymphocyte recruitment to the lungs during the adaptive phase of immunity against $C$. neoformans $52 \mathrm{D}$ infection.

\section{Pulmonary CD4 ${ }^{+}$T Cells from IL-1RI-/- Mice Display Diminished Th17 and Increased Th2 Cytokine Production following C. neoformans Infection}

It has been clearly shown that a Th1/Th17 response is protective and a Th2 response is detrimental, respectively, against C. neoformans infection (60). To analyze the effect of IL-1R signaling on $\mathrm{T}$ cell differentiation during infection, we harvested lungs at serial time points, restimulated the cells with PMA/ionomycin, and stained for intracellular IFN $\gamma$, IL-13, and IL-17A as representative cytokines for Th1, Th2, and Th17 polarization states, respectively (Figure 9). The results 
A

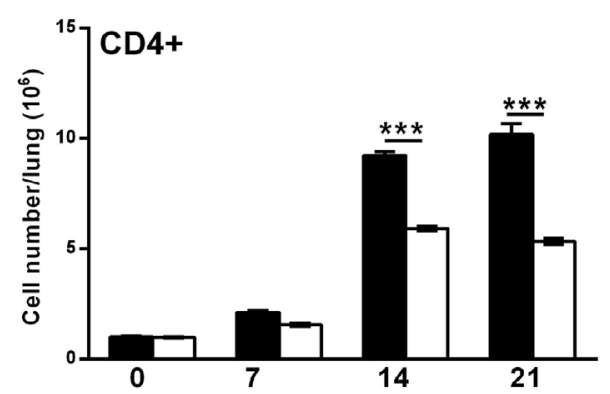

C

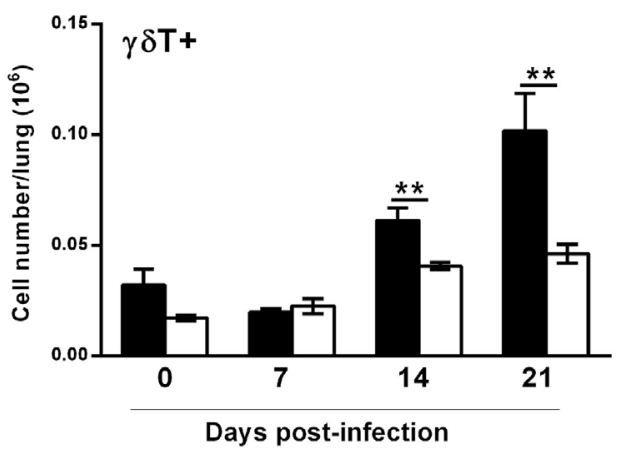

B

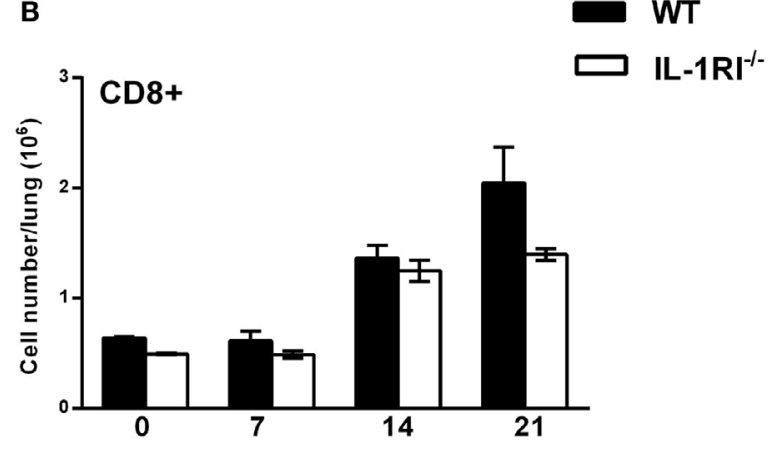

D

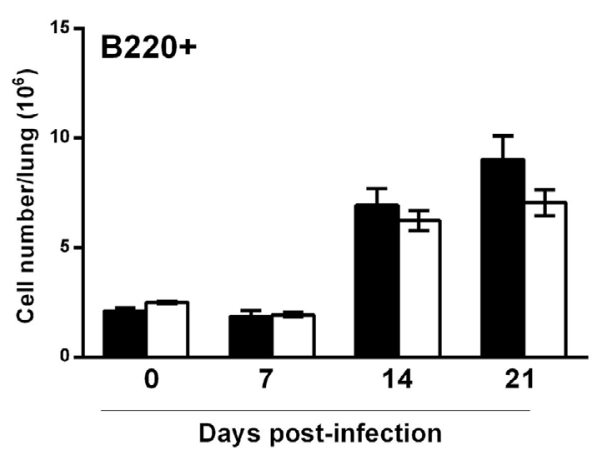

FIGURE 8 | Lungs of interleukin-1 receptor type l-deficient (IL-1RI $\left.\left.\right|^{-/}\right)$mice display fewer $\mathrm{CD}^{+}$and $\gamma \delta \mathrm{T}^{+}$lymphocytes during the adaptive phase of immunity after Cryptococcus neoformans 52D infection. Lung cell suspensions from uninfected and infected mice were stained with fluorochrome-labeled antibodies and analyzed by flow cytometry as described in Section "Materials and Methods." (A-D) Total number of CD3 ${ }^{+} \mathrm{CD} 4^{+}, \mathrm{CD}^{+} \mathrm{CD} 8^{+}, \mathrm{CD} 3^{+} \gamma \delta^{+}$, and $\mathrm{B} 22 \mathrm{O}^{+}$cells in the lungs at 0,7 , 14 , and 21 days postinfection. Data are shown as mean \pm SEM and representative of two independent experiments $\left(n=4\right.$ mice/strain/time point). ${ }^{\star \star} P \leq 0.01$ and ${ }^{\star * *} P \leq 0.001$.

demonstrated a significantly higher number of $\mathrm{CD}^{+}{ }^{+} \mathrm{IFN} \gamma^{+}$ cells in the lungs of WT compared to IL-1RI-/- mice at 7 days postinfection with a trend toward more $\mathrm{CD}^{+} \mathrm{IFN} \gamma^{+}$cells at days 14 and 21. Compared to the $\mathrm{IL}-1 \mathrm{RI}^{-1-}$ strain, WT mice showed a trend toward more $\mathrm{CD} 4^{+} \mathrm{IL}-17 \mathrm{~A}^{+}$cells at day 7 with a significant increase of this cell type at days 14 and 21 . In contrast, IL-1RI ${ }^{-/-}$lungs contained a significantly higher percentage of $\mathrm{CD}^{+} \mathrm{IL} 3^{+}$cells compared to WT lungs at 14 and 21 days postinfection. In summary, these findings demonstrate that after C. neoformans infection, IL-1RI signaling significantly increased Th1 differentiation during the early phase of infection and strongly promoted Th17 differentiation during the late phase of infection.

\section{DISCUSSION}

Induction of IL- $1 \alpha / \beta$ during mouse cryptococcal infection has been reported, but a clear role for IL-1R-dependent signaling in the host immune response has not been demonstrated $(27,32$, $34,35,37)$. Here, we provide evidence that IL-1RI deficiency on the BALB/c background has deleterious effects on the outcome of pulmonary C. neoformans 52D infection. The most significant findings of this study are as follows: (1) IL-1RI $\mathrm{RI}^{-/-}$mice cannot clear moderately virulent $C$. neoformans $52 \mathrm{D}$ and develop progressive infection of the lungs and brain resulting in death starting at day 40 postinfection; (2) susceptibility of IL-1RI ${ }^{-/-}$mice is associated with reduced levels of pro-inflammatory, Th1, and Th17 cytokines; (3) IL-1RI signaling in response to C. neoformans $52 \mathrm{D}$ infection regulates the recruitment of inflammatory DCs to the lung, contributes to recruitment and M1 polarization of macrophages, and promotes Th1/Th17 differentiation of $\mathrm{CD}^{+}$ T cells; and (4) lung neutrophil recruitment associated with IL-1R signaling is dispensable for protection against C. neoformans 52D infection. Taken together, these data clearly demonstrate that IL-1R-dependent signaling plays a complex and essential role in the control of progressive C. neoformans 52D infection.

Previously, intranasal infection of C57BL/6 and $\mathrm{IL}_{-1 \mathrm{RI}^{-/-}}$mice with $2 \times 10^{4} \mathrm{CFU}$ of the virulent $C$. neoformans $\mathrm{H} 99$ strain was shown to cause $>90 \%$ mortality in both groups (37). In the same report, mice lacking MyD88, an intracellular adaptor for IL-1RI, IL-18R, and several Toll-like receptors, had a trend toward reduced survival but no significant difference in fungal burden compared to WT mice after C. neoformans challenge (37). Notably, two earlier studies showed that MyD88 ${ }^{-/-}$mice have a significantly shorter survival time and a higher lung fungal burden compared to WT, $\mathrm{TLR}^{-/-}$, and TLR4 ${ }^{-/-}$mice after C. neoformans infection $(61,62)$. These differences may be attributable, at least in part, to variation in the experimental methods that were used including the dose, 

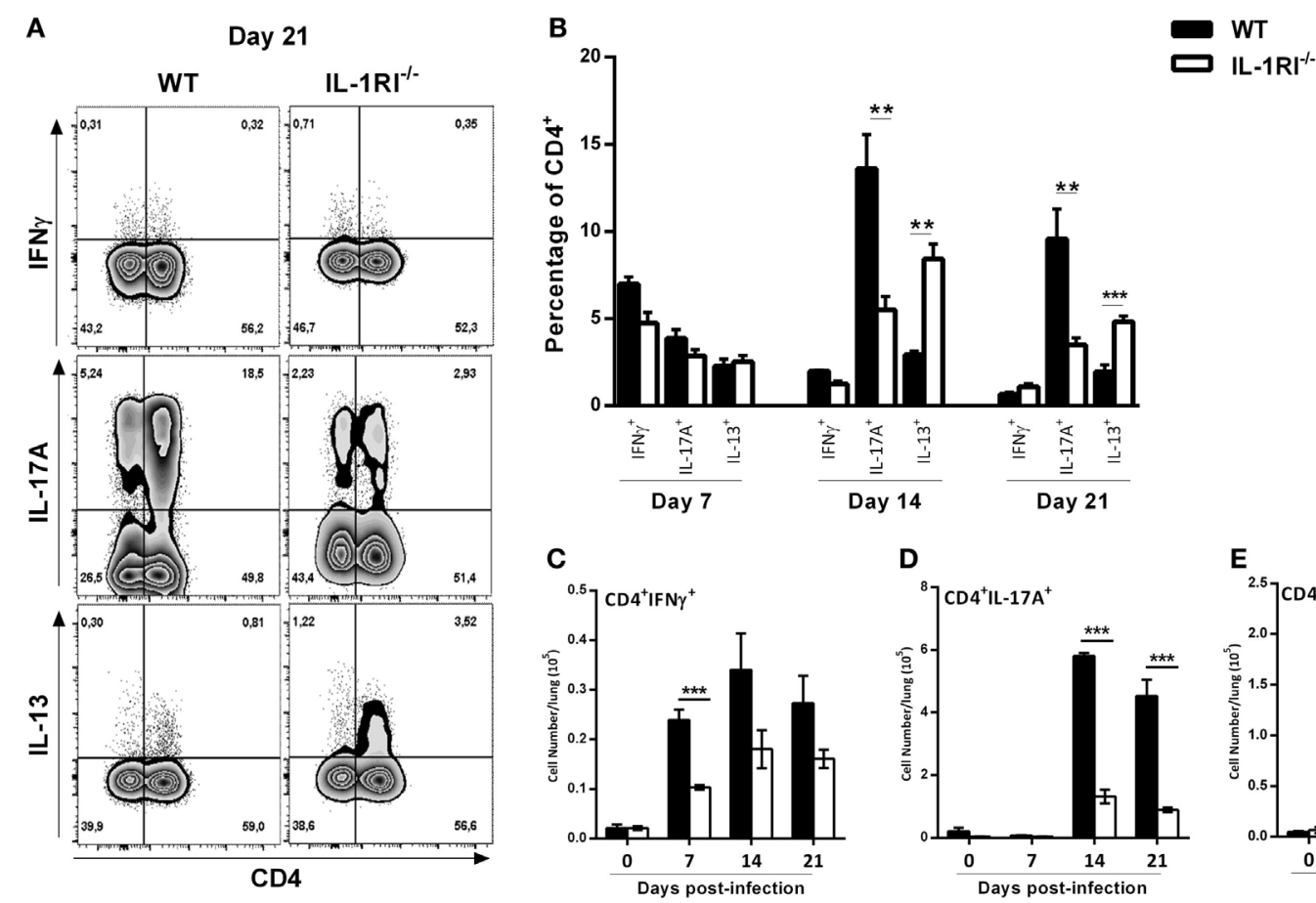

FIGURE 9 | Decreased Th1/Th17 type cytokine expression by CD4+ T cells from interleukin-1 receptor type l-deficient (IL-1RI ${ }^{-/-}$) lungs infected with Cryptococcus neoformans 52D. (A) Representative flow cytometry plots of lung lymphocytes from individual mice harvested at 14 days postinfection and restimulated with phorbo 12-myristate 13-acetate (PMA)-ionomycin, followed by intracellular staining for IFN $\gamma, I L-17 A$, and IL-13. (B) Percentage and (C-E) total numbers of CD4+IFN+, $\mathrm{CD} 4^{+} \mathrm{IL}-17 \mathrm{~A}^{+}$and $\mathrm{CD} 4^{+} \mathrm{IL} 13^{+}$cells are shown. Data are shown as mean $\pm \mathrm{SEM}$ and representative of two independent experiments $(n=4 \mathrm{mice} /$ strain/time point). ${ }^{\star} P \leq 0.05,{ }^{\star \star} P \leq 0.01$, and ${ }^{\star \star \star} P \leq 0.001$. WT, wild type.

route, and strain of C. neoformans (60, 63-65). Furthermore, inbred mouse strains also display marked differences in resistance or susceptibility to a standardized cryptococcal infection, highlighting the importance of the host genetic background in disease pathogenesis (66-68). Our data are consistent with other studies showing that $\mathrm{BALB} / \mathrm{c}$ mice have a naturally resistant phenotype after respiratory infection with the moderately virulent $C$. neoformans 52D strain. Specifically, BALB/c mice progressively clear pulmonary C. neoformans 52D infection in association with numerous hallmarks of a protective Th1 response including tight mononuclear cell infiltrates and classically activated macrophages and do not develop central nervous system dissemination $(18,66$, $69,70)$. Our observation that both IL- $1 \alpha$ and IL- $1 \beta$ were induced in the lungs of BALB/c mice after intratracheal infection with $C$. neoformans 52D is also consistent with earlier reports that associated the induction of IL- $1 \beta$ in lung and brain with resistance to cryptococcal infection $(35,71,72)$.

Interleukin-1 is a central mediator of inflammation and links innate and adaptive immune response mechanisms (73). Binding of IL- $1 \alpha$ or IL-1 $\beta$ to IL-1RI is followed by the recruitment of the IL-1 receptor accessory protein (IL-1RAcP) and activation of signal transduction pathways that induce the expression of IL-1 responsive genes including IL-6, MCP-1, and TNF $\alpha$ (74-77). Induction of pro-inflammatory cytokines followed by generation of a Th1 adaptive immune response is critical for control of cryptococcosis $(8,11,78)$. Compared to the BALB/c strain,
IL-1RI ${ }^{-/-}$mice had significantly reduced expression of $\mathrm{KC}, \mathrm{TNF} \alpha$, and MCP-1 that was associated with increased lung fungal burden at day 7 after infection. TNF $\alpha$ is one of the main target genes of the IL-1 signaling cascade $(76,77)$, and both mediators share downstream pathways that induce pro-inflammatory gene expression $(79,80)$. TNF $\alpha$ signaling in the afferent phase of cryptococcal infection is associated with optimal DC activation and induction of Th1/Th17 polarization and protective immunity $(78,81-84)$. MCP1/CCR2 signaling is also responsible for the recruitment of inflammatory DCs and macrophages after cryptococcal infection $(45,46,85)$. Thus, the reduced expression of pro-inflammatory cytokines and chemokines is one mechanism that could explain the susceptibility of IL-1 $\mathrm{RI}^{-/-}$mice to progressive cryptococcosis.

After C. neoformans infection, DCs phagocytose and kill cryptococci by oxidative and non-oxidative mechanisms, play an important role in antigen presentation, and drive protective immune responses by secreting cytokines and chemokines (86-89). Compared to other innate cell types, lung DCs express a high level of IL-1RI and signaling via this receptor has been shown to promote the maturation and survival of pulmonary DCs and their CCR7-dependent migration to lymph nodes after Influenza A infection (90). At 21 days postinfection with C. neoformans, the total number of moDCs in the lung was significantly lower in IL-1RI ${ }^{-/}$compared to WT mice, suggesting that recruitment and activation of DCs in the LALNs may be regulated by IL-1R signaling in this model. In addition to DCs, inflammatory macrophages 
that strongly express microbicidal enzymes such as iNOS play a significant role in fungal clearance $(45,46,69,91)$. After $C$. neoformans 52D infection, we observed that lung macrophages of IL- $1 \mathrm{R}^{-/-}$mice had reduced expression of the classical activation markers CD80 and iNOS and increased expression of the alternative activation marker CD206 compared to WT, a pattern that is associated with reduced fungal killing capacity. Our findings are similar to a recent study in $\mathrm{BALB} / \mathrm{c}$ mice infected with $C$. neoformans 52D that correlated an elevated ratio of Arg1/iNOS expression with an increase in fungal burden and showed a reversal of this ratio during the subsequent period of fungal clearance (48).

In addition to monocyte-derived macrophages and DCs, significantly greater neutrophil recruitment was observed in WT compared to IL- $1 \mathrm{R}^{-1-}$ lungs. Both IL- $1 \alpha$ and IL- $1 \beta$ can promote neutrophil migration (92-95), and diminished neutrophil recruitment to the site of infection due to IL-1R deficiency has been associated with increased susceptibility to several bacterial and fungal infections including Legionella pneumophila, Group B Streptococcus, Citrobacter rodentium, and Candida albicans (55, 96-100). Inbred mouse strains including SJL/J, CBA/J, and $\mathrm{BALB} / \mathrm{c}$ are naturally resistant to pulmonary cryptococcal infection and exhibit substantial neutrophil recruitment the lungs; however, the importance of these cells in host protection is not clear $(35,67,68)$. For example, an early study of BALB/c mice given a single injection of anti-Gr-1 (anti-Ly6C/6G) antibody showed less inflammatory damage and significantly longer survival compared to controls after C. neoformans 52D infection (101). A subsequent study of BALB/c mice that had undergone prior immunization with $C$. neoformans strain $\mathrm{H} 99 \gamma$ showed that neutrophil depletion with a specific anti-Ly6G antibody did not affect pulmonary fungal burden (102). Finally, a recent report showed that profound neutrophilia in type 2-deficient STAT6 ${ }^{-1-}$ mice on a C57BL/6 background was associated with immunopathology and exacerbation of cryptococcal disease (103). To specifically analyze the contribution of neutrophils to resistance against $C$. neoformans 52D, we used anti-Ly6G to deplete these cells in WT BALB/c mice throughout the course of infection $(104,105)$. In the absence of neutrophil recruitment, we observed a significantly lower lung fungal burden at 12 days postinfection compared to controls. This finding suggests that, despite their abundance in the lung, neutrophils may have a detrimental effect on host defense against moderately virulent $C$. neoformans 52D (101). Several mechanisms may explain this observation, including competition for cryptococcal antigen between neutrophils and antigen-presenting cells, neutrophil secretion of the immunosuppressive cytokine TGF $\beta 1$, or production of IL-1 receptor antagonist, a molecule that inhibits IL-1R signaling $(100,106-110)$. Further research is necessary to precisely establish the physiological mechanisms that control neutrophil recruitment during cryptococcal infection and to determine whether these cells make a positive contribution to host resistance.

Along with reduced pro-inflammatory cytokines, IL-1 $\mathrm{R}^{-/-}$mice showed diminished levels of lung IFN $\gamma$ compared to WT mice at the early (day 7) and late (days 14 and 21) phases of infection. Intracellular cytokine staining identified $\mathrm{CD} 4^{+}$lymphocytes as the most prominent IFN $\gamma$-producing cell type. As very few studies have identified IL-1R expression on Th1 cells (111), induction of
IFN $\gamma$ expression by $\mathrm{CD}^{+} \mathrm{T}$ cells appears to be an indirect effect of IL-1RI signaling on DCs and possibly other cell types (90). IFN $\gamma$ plays a central role in host defense against cryptococci by enhancing the fungal internalization and killing by phagocytes $(78,83)$. An important role for early IFN $\gamma$ secretion and the development of a Th1 response against C. neoformans 52D infection was previously shown in resistant C.B-17 mice (a BALB/c strain congenic for $\mathrm{C} 57 \mathrm{BL} / 6$ immunoglobulin heavy chain gene segment), whereas the absence of this response in the C57BL/6 strain correlated with susceptibility (11).

IL-1 is known to regulate the expression of the transcription factors IRF4 and ROR $\gamma \mathrm{t}$, both of which play a major role in the induction of $\mathrm{CD}^{+} \mathrm{IL}-17^{+}$(Th17) cells in mice and humans (112-114). IL-1 signaling has been shown to be essential for the development of Th17 immunity to infection with Coccidioides $s p$ (115), and mice with deletions of IL-17 or IL-17R are susceptible to candidiasis, pulmonary aspergillosis, and histoplasmosis (55). The role of IL-17 during cryptococcal infection has been analyzed using mice with a C57BL/6 genetic background. In one study, IL-17RA deficiency did not impair pulmonary clearance of C. neoformans 52D at 1 or 6 weeks postinfection nor did it alter survival compared to WT mice (116). Another study using IL-17A-deficient mice showed that this cytokine does contribute to fungal clearance from the lung but was not essential for 8-week survival (19). In contrast, administration of IL-23, which is essential for the differentiation of Th17 lymphocytes, led to prolonged survival and reduced fungal burden in C57BL/6 mice (22). A Th17-polarized immune response appears to facilitate the resolution of $C$. neoformans 52D infection through several mechanisms including lung recruitment of activated DCs and inflammatory macrophages, induction of IFN $\gamma$-producing $\mathrm{CD}^{+}$ and $\mathrm{CD}^{+} \mathrm{T}$ cells, and enhanced fungal containment within macrophages (19-22). Compared to BALB/c, IL-1R $\mathrm{R}^{-1-}$ mice display several phenotypes that may be attributable to a diminished Th17 response including reduced recruitment of DCs and inflammatory macrophages and increased recruitment of eosinophils and $\mathrm{CD} 4^{+} \mathrm{IL}-13^{+}$cells to the lungs. On the basis of marked difference between WT and IL-1 $\mathrm{R}^{-/-}$mice, we speculate that IL-17 plays a non-redundant role in survival after $C$. neoformans 52D infection; however, studies of BALB/c mice that are deficient for IL-17 or IL-17RA would be required to formally test this hypothesis.

In mouse models, IL-1 signaling is protective against infection with a wide spectrum of intracellular pathogens including Leishmania amazonensis, Mycobacterium avium, Toxoplasma gondii, and Listeria monocytogenes (117-121). IL-1RI-deficient mice are also highly susceptible to pulmonary challenge with Aspergillus fumigatus; in this model, IL- $1 \alpha$ has been shown to be crucial for optimal leukocyte recruitment and IL-1 $\beta$ has been shown to be essential for optimal activation of macrophage antifungal activity (122). It has been suggested that polymorphisms in the IL-1 gene cluster might be important in susceptibility or resistance to invasive pulmonary aspergillosis in humans $(123,124)$. Both IL- $1 \alpha$ and IL- $1 \beta$ have also been shown to play an important role in disseminated candidiasis (125-128), and IL-1 signaling has shown to contribute to host resistance against pulmonary histoplasmosis and Coccidioides sp. infection $(115,129)$. This study expands the role of IL-1 in host defense 
by demonstrating that IL-1R $\mathrm{R}^{-/-}$mice on the Balb/c background are highly susceptible to progressive $C$. neoformans 52D infection of the lungs and brain. IL-1R deficiency in this model results in impaired Th1/Th17 responses and the development of a Th2-biased adaptive immune response. As IL- $1 \alpha$ and IL- $1 \beta$ are equally potent activators of IL-1RI signaling yet have different tissue distribution and activation kinetics, future studies that characterize mice that are deficient in either IL- $1 \alpha$ or IL- $1 \beta$ or the study of specific cytokine-deficient animals would provide valuable insights into the specific contributions of each cytokine to the development of protective immunity against $C$. neoformans infection.

\section{ETHICS STATEMENT}

This study was carried out in accordance with the recommendations of the Canadian Council on Animal Care guidelines. The protocol was approved by the McGill University Animal Care Committee.

\section{AUTHOR CONTRIBUTIONS}

MS conceived and performed experiments and wrote/edited the manuscript for important intellectual content. BR and IA

\section{REFERENCES}

1. Rajasingham R, Smith RM, Park BJ, Jarvis JN, Govender NP, Chiller TM, et al. Global burden of disease of HIV-associated cryptococcal meningitis: an updated analysis. Lancet Infect Dis (2017) 17(8):873-81. doi:10.1016/ S1473-3099(17)30243-8

2. Adams P. Cryptococcal meningitis: a blind spot in curbing AIDS. Lancet (2016) 387(10028):1605-6. doi:10.1016/S0140-6736(16)30250-1

3. Hole C, Wormley FL Jr. Innate host defenses against Cryptococcus neoformans. J Microbiol (2016) 54(3):202-11. doi:10.1007/s12275-016-5625-7

4. Neofytos D, Fishman JA, Horn D, Anaissie E, Chang CH, Olyaei A, et al. Epidemiology and outcome of invasive fungal infections in solid organ transplant recipients. Transpl Infect Dis (2010) 12(3):220-9. doi:10.1111/ j.1399-3062.2010.00492.x

5. Pappas PG. Cryptococcal infections in non-HIV-infected patients. Trans Am Clin Climatol Assoc (2013) 124:61-79.

6. Brizendine KD, Baddley JW, Pappas PG. Predictors of mortality and differences in clinical features among patients with Cryptococcosis according to immune status. PLoS One (2013) 8(3):e60431. doi:10.1371/journal.pone. 0060431

7. Panackal AA, Wuest SC, Lin YC, Wu T, Zhang N, Kosa P, et al. Paradoxical immune responses in non-HIV cryptococcal meningitis. PLoS Pathog (2015) 11(5):e1004884. doi:10.1371/journal.ppat.1004884

8. Arora S, Olszewski MA, Tsang TM, McDonald RA, Toews GB, Huffnagle GB. Effect of cytokine interplay on macrophage polarization during chronic pulmonary infection with Cryptococcus neoformans. Infect Immun (2011) 79(5):1915-26. doi:10.1128/IAI.01270-10

9. Leopold Wager CM, Wormley FL Jr. Classical versus alternative macrophage activation: the Ying and the Yang in host defense against pulmonary fungal infections. Mucosal Immunol (2014) 7(5):1023-35. doi:10.1038/ mi.2014.65

10. Koguchi Y, Kawakami K. Cryptococcal infection and Th1-Th2 cytokine balance. Int Rev Immunol (2002) 21(4-5):423-38. doi:10.1080/08830180213274

11. Hoag KA, Street NE, Huffnagle GB, Lipscomb MF. Early cytokine production in pulmonary Cryptococcus neoformans infections distinguishes susceptible and resistant mice. Am J Respir Cell Mol Biol (1995) 13(4):487-95. doi:10.1165/ajrcmb.13.4.7546779

12. Chen GH, McDonald RA, Wells JC, Huffnagle GB, Lukacs NW, Toews GB. The gamma interferon receptor is required for the protective pulmonary performed experiments and edited the manuscript for important intellectual content. DS provided reagents and edited the manuscript for important intellectual content. SQ conceived, designed, and supervised the study and wrote/edited the manuscript for important intellectual content.

\section{ACKNOWLEDGMENTS}

We thank the histology core facility of the Bellini Life Sciences Complex for assistance with lung tissue preparation and staining.

\section{FUNDING}

This work was supported by grants to the Research Institute of the McGill University Health Centre and a Research Chair (DS) from the Fonds de Recherche Santé Quebec, the Canadian Institutes of Health Research to SQ (MOP102494) and DS (MOP-81361 and MOP-123306), the Costello Memorial Research Fund (SQ), and the Research Institute and Department of Critical Care of the McGill University Health Centre (SQ).

inflammatory response to Cryptococcus neoformans. Infect Immun (2005) 73(3):1788-96. doi:10.1128/IAI.73.3.1788-1796.2005

13. Hoag KA, Lipscomb MF, Izzo AA, Street NE. IL-12 and IFN-gamma are required for initiating the protective Th1 response to pulmonary cryptococcosis in resistant C.B-17 mice. Am J Respir Cell Mol Biol (1997) 17(6):733-9. doi:10.1165/ajrcmb.17.6.2879

14. Kawakami K, Qureshi MH, Zhang T, Koguchi Y, Shibuya K, Naoe S, et al. Interferon-gamma (IFN-gamma)-dependent protection and synthesis of chemoattractants for mononuclear leucocytes caused by IL-12 in the lungs of mice infected with Cryptococcus neoformans. Clin Exp Immunol (1999) 117(1):113-22. doi:10.1046/j.1365-2249.1999.00955.x

15. Pietrella D, Lupo P, Bistoni F, Vecchiarelli A. An early imbalance of interleukin 12 influences the adjuvant effect of mannoproteins of Cryptococcus neoformans. Cell Microbiol (2004) 6(9):883-91. doi:10.1111/j.1462-5822.2004. 00411.x

16. Blackstock R, Murphy JW. Role of interleukin-4 in resistance to Cryptococcus neoformans infection. Am JRespir Cell Mol Biol (2004) 30(1):109-17. doi:10.1165/rcmb.2003-0156OC

17. Muller U, Stenzel W, Kohler G, Werner C, Polte T, Hansen G, et al. IL-13 induces disease-promoting type 2 cytokines, alternatively activated macrophages and allergic inflammation during pulmonary infection of mice with Cryptococcus neoformans. J Immunol (2007) 179(8):5367-77. doi:10.4049/ jimmunol.179.8.5367

18. Jain AV, Zhang Y, Fields WB, McNamara DA, Choe MY, Chen GH, et al. Th2 but not Th1 immune bias results in altered lung functions in a murine model of pulmonary Cryptococcus neoformans infection. Infect Immun (2009) 77(12):5389-99. doi:10.1128/IAI.00809-09

19. Murdock BJ, Huffnagle GB, Olszewski MA, Osterholzer JJ. Interleukin17A enhances host defense against cryptococcal lung infection through effects mediated by leukocyte recruitment, activation, and gamma interferon production. Infect Immun (2014) 82(3):937-48. doi:10.1128/ IAI.01477-13

20. Valdez PA, Vithayathil PJ, Janelsins BM, Shaffer AL, Williamson PR, Datta SK. Prostaglandin E2 suppresses antifungal immunity by inhibiting interferon regulatory factor 4 function and interleukin-17 expression in $\mathrm{T}$ cells. Immunity (2012) 36(4):668-79. doi:10.1016/j.immuni.2012.02.013

21. Zhang Y, Wang F, Tompkins KC, McNamara A, Jain AV, Moore BB, et al. Robust Th1 and Th17 immunity supports pulmonary clearance but cannot prevent systemic dissemination of highly virulent Cryptococcus 
neoformans H99. Am J Pathol (2009) 175(6):2489-500. doi:10.2353/ajpath. 2009.090530

22. Kleinschek MA, Muller U, Schutze N, Sabat R, Straubinger RK, Blumenschein WM, et al. Administration of IL-23 engages innate and adaptive immune mechanisms during fungal infection. Int Immunol (2010) 22(2):81-90. doi:10.1093/intimm/dxp117

23. Kleinschek MA, Muller U, Brodie SJ, Stenzel W, Kohler G, Blumenschein WM, et al. IL-23 enhances the inflammatory cell response in Cryptococcus neoformans infection and induces a cytokine pattern distinct from IL-12.J Immunol (2006) 176(2):1098-106. doi:10.4049/jimmunol.176.2.1098

24. Hardison SE, Wozniak KL, Kolls JK, Wormley FL Jr. Interleukin-17 is not required for classical macrophage activation in a pulmonary mouse model of Cryptococcus neoformans infection. Infect Immun (2010) 78(12):5341-51. doi:10.1128/IAI.00845-10

25. Wozniak KL, Hardison SE, Kolls JK, Wormley FL. Role of IL-17A on resolution of pulmonary C. neoformans infection. PLoS One (2011) 6(2):e17204. doi:10.1371/journal.pone.0017204

26. Marais S, Meintjes G, Lesosky M, Wilkinson KA, Wilkinson RJ. Interleukin-17 mediated differences in the pathogenesis of HIV-1-associated tuberculous and cryptococcal meningitis. AIDS (2016) 30(3):395-404. doi:10.1097/ QAD.0000000000000904

27. Vecchiarelli A, Retini C, Pietrella D, Monari C, Tascini C, Beccari T, et al. Downregulation by cryptococcal polysaccharide of tumor necrosis factor alpha and interleukin- 1 beta secretion from human monocytes. Infect Immun (1995) 63(8):2919-23.

28. Retini C, Vecchiarelli A, Monari C, Tascini C, Bistoni F, Kozel TR. Capsular polysaccharide of Cryptococcus neoformans induces proinflammatory cytokine release by human neutrophils. Infect Immun (1996) 64(8):2897-903.

29. Delfino D, Cianci L, Lupis E, Celeste A, Petrelli ML, Curro F, et al. Interleukin-6 production by human monocytes stimulated with Cryptococcus neoformans components. Infect Immun (1997) 65(6):2454-6.

30. Levitz SM, Tabuni A, Kornfeld H, Reardon CC, Golenbock DT. Production of tumor necrosis factor alpha in human leukocytes stimulated by Cryptococcus neoformans. Infect Immun (1994) 62(5):1975-81.

31. Vecchiarelli A, Retini C, Monari C, Tascini C, Bistoni F, Kozel TR. Purified capsular polysaccharide of Cryptococcus neoformans induces interleukin-10 secretion by human monocytes. Infect Immun (1996) 64(7):2846-9.

32. Schoffelen T, Illnait-Zaragozi MT, Joosten LA, Netea MG, Boekhout T, Meis JF, et al. Cryptococcus gattii induces a cytokine pattern that is distinct from other cryptococcal species. PLoS One (2013) 8(1):e55579. doi:10.1371/ journal.pone.0055579

33. Marroni M, Pericolini E, Cenci E, Bistoni F, Vecchiarelli A. Functional defect of natural immune system in an apparent immunocompetent patient with pulmonary cryptococcosis. J Infect (2007) 54(1):e5-8. doi:10.1016/j. jinf.2006.03.018

34. Chen M, Xing Y, Lu A, Fang W, Sun B, Chen C, et al. Internalized Cryptococcus neoformans activates the canonical caspase- 1 and the noncanonical caspase-8 inflammasomes. J Immunol (2015) 195(10):4962-72. doi:10.4049/ jimmunol.1500865

35. Guillot L, Carroll SF, Homer R, Qureshi ST. Enhanced innate immune responsiveness to pulmonary Cryptococcus neoformans infection is associated with resistance to progressive infection. Infect Immun (2008) 76(10):4745-56. doi:10.1128/IAI.00341-08

36. Subramaniam KS, Datta K, Quintero E, Manix C, Marks MS, Pirofski LA. The absence of serum IgM enhances the susceptibility of mice to pulmonary challenge with Cryptococcus neoformans. J Immunol (2010) 184(10):5755-67. doi:10.4049/jimmunol.0901638

37. Wang JP, Lee CK, Akalin A, Finberg RW, Levitz SM. Contributions of the MyD88-dependent receptors IL-18R, IL-1R, and TLR9 to host defenses following pulmonary challenge with Cryptococcus neoformans. PLoS One (2011) 6(10):e26232. doi:10.1371/journal.pone.0026232

38. Nakamura K, Miyagi K, Koguchi Y, Kinjo Y, Uezu K, Kinjo T, et al. Limited contribution of Toll-like receptor 2 and 4 to the host response to a fungal infectious pathogen, Cryptococcus neoformans. FEMS Immunol Med Microbiol (2006) 47(1):148-54. doi:10.1111/j.1574-695X.2006.00078.x

39. Upadhya R, Lam WC, Maybruck B, Specht CA, Levitz SM, Lodge JK. Induction of protective immunity to cryptococcal infection in mice by a heat-killed, chitosan-deficient strain of Cryptococcus neoformans. MBio (2016) 7(3):e547-516. doi:10.1128/mBio.00547-16
40. Uicker WC, Doyle HA, McCracken JP, Langlois M, Buchanan KL. Cytokine and chemokine expression in the central nervous system associated with protective cell-mediated immunity against Cryptococcus neoformans. Med Mycol (2005) 43(1):27-38. doi:10.1080/13693780410001731510

41. Lei G, Chen M, Li H, Niu JL, Wu S, Mao L, et al. Biofilm from a clinical strain of Cryptococcus neoformans activates the NLRP3 inflammasome. Cell Res (2013) 23(7):965-8. doi:10.1038/cr.2013.49

42. Roussey JA, Viglianti SP, Teitz-Tennenbaum S, Olszewski MA, Osterholzer JJ. Anti-PD-1 antibody treatment promotes clearance of persistent cryptococcal lung infection in mice. J Immunol (2017) 199(10):3535-46. doi:10.4049/ jimmunol.1700840

43. Misharin AV, Morales-Nebreda L, Mutlu GM, Budinger GR, Perlman H. Flow cytometric analysis of macrophages and dendritic cell subsets in the mouse lung. Am J Respir Cell Mol Biol (2013) 49(4):503-10. doi:10.1165/ rcmb.2013-0086MA

44. Guilliams M, Lambrecht BN, Hammad H. Division of labor between lung dendritic cells and macrophages in the defense against pulmonary infections. Mucosal Immunol (2013) 6(3):464-73. doi:10.1038/mi.2013.14

45. Osterholzer JJ, Chen GH, Olszewski MA, Zhang YM, Curtis JL, Huffnagle GB, et al. Chemokine receptor 2-mediated accumulation of fungicidal exudate macrophages in mice that clear cryptococcal lung infection. Am J Pathol (2011) 178(1):198-211. doi:10.1016/j.ajpath.2010.11.006

46. Osterholzer JJ, Curtis JL, Polak T, Ames T, Chen GH, McDonald R, et al. CCR2 mediates conventional dendritic cell recruitment and the formation of bronchovascular mononuclear cell infiltrates in the lungs of mice infected with Cryptococcus neoformans. JImmunol (2008) 181(1):610-20. doi:10.4049/jimmunol.181.1.610

47. Xu J, Flaczyk A, Neal LM, Fa Z, Cheng D, Ivey M, et al. Exploitation of scavenger receptor, macrophage receptor with collagenous structure, by Cryptococcus neoformans promotes alternative activation of pulmonary lymph node $\mathrm{CD} 11 \mathrm{~b}(+)$ conventional dendritic cells and non-protective Th2 bias. Front Immunol (2017) 8:1231. doi:10.3389/fimmu.2017.01231

48. Davis MJ, Tsang TM, Qiu Y, Dayrit JK, Freij JB, Huffnagle GB, et al. Macrophage M1/M2 polarization dynamically adapts to changes in cytokine microenvironments in Cryptococcus neoformans infection. MBio (2013) 4(3):e264-213. doi:10.1128/mBio.00264-13

49. Sica A, Mantovani A. Macrophage plasticity and polarization: in vivo veritas. J Clin Invest (2012) 122(3):787-95. doi:10.1172/JCI59643

50. Murray PJ, Allen JE, Biswas SK, Fisher EA, Gilroy DW, Goerdt S, et al. Macrophage activation and polarization: nomenclature and experimental guidelines. Immunity (2014) 41(1):14-20. doi:10.1016/j.immuni.2014. 06.008

51. May RC, Stone NR, Wiesner DL, Bicanic T, Nielsen K. Cryptococcus: from environmental saprophyte to global pathogen. Nat Rev Microbiol (2016) 14(2):106-17. doi:10.1038/nrmicro.2015.6

52. Mantovani A, Sica A, Sozzani S, Allavena P, Vecchi A, Locati M. The chemokine system in diverse forms of macrophage activation and polarization. Trends Immunol (2004) 25(12):677-86. doi:10.1016/j.it.2004.09.015

53. Mantovani A, Sozzani S, Locati M, Allavena P, Sica A. Macrophage polarization: tumor-associated macrophages as a paradigm for polarized M2 mononuclear phagocytes. Trends Immunol (2002) 23(11):549-55. doi:10.1016/ S1471-4906(02)02302-5

54. Veldhoen M. Interleukin 17 is a chief orchestrator of immunity. Nat Immunol (2017) 18(6):612-21. doi:10.1038/ni.3742

55. Underhill DM, Pearlman E. Immune interactions with pathogenic and commensal fungi: a two-way street. Immunity (2015) 43(5):845-58. doi:10.1016/j. immuni.2015.10.023

56. Gladiator A, Wangler N, Trautwein-Weidner K, LeibundGut-Landmann S. Cutting edge: IL-17-secreting innate lymphoid cells are essential for host defense against fungal infection. J Immunol (2013) 190(2):521-5. doi:10.4049/ jimmunol.1202924

57. Gozalbo D, Gil ML. IFN-gamma in Candida albicans infections. Front Biosci (Landmark Ed) (2009) 14:1970-8. doi:10.2741/3356

58. Romani L. Immunity to fungal infections. Nat Rev Immunol (2011) 11(4):275-88. doi:10.1038/nri2939

59. Rodrigues DR, Fernandes RK, Balderramas Hde A, Penitenti M, Bachiega TF, Calvi SA, et al. Interferon-gamma production by human neutrophils upon stimulation by IL-12, IL-15 and IL-18 and challenge with Paracoccidioides brasiliensis. Cytokine (2014) 69(1):102-9. doi:10.1016/j.cyto.2014.05.009 
60. Voelz K, May RC. Cryptococcal interactions with the host immune system. Eukaryot Cell (2010) 9(6):835-46. doi:10.1128/EC.00039-10

61. Biondo C, Midiri A, Messina L, Tomasello F, Garufi G, Catania MR, et al. MyD88 and TLR2, but not TLR4, are required for host defense against Cryptococcus neoformans. Eur J Immunol (2005) 35(3):870-8. doi:10.1002/ eji.200425799

62. Yauch LE, Mansour MK, Shoham S, Rottman JB, Levitz SM. Involvement of CD14, toll-like receptors 2 and 4, and MyD88 in the host response to the fungal pathogen Cryptococcus neoformans in vivo. Infect Immun (2004) 72(9):5373-82. doi:10.1128/IAI.72.9.5373-5382.2004

63. Olszewski MA, Zhang Y, Huffnagle GB. Mechanisms of cryptococcal virulence and persistence. Future Microbiol (2010) 5(8):1269-88. doi:10.2217/ fmb. 10.93

64. Urai M, Kaneko Y, Ueno K, Okubo Y, Aizawa T, Fukazawa H, et al. Evasion of innate immune responses by the highly virulent Cryptococcus gattii by altering capsule glucuronoxylomannan structure. Front Cell Infect Microbiol (2015) 5:101. doi:10.3389/fcimb.2015.00101

65. Montone KT. Regulating the T-cell immune response toward the H99 strain of Cryptococcus neoformans. Am J Pathol (2009) 175(6):2255-6. doi:10.2353/ ajpath.2009.090891

66. Chen GH, McNamara DA, Hernandez Y, Huffnagle GB, Toews GB, Olszewski MA. Inheritance of immune polarization patterns is linked to resistance versus susceptibility to Cryptococcus neoformans in a mouse model. Infect Immun (2008) 76(6):2379-91. doi:10.1128/IAI.01143-07

67. Carroll SF, Lafferty EI, Flaczyk A, Fujiwara TM, Homer R, Morgan K, et al. Susceptibility to progressive Cryptococcus neoformans pulmonary infection is regulated by loci on mouse chromosomes 1 and 9. Infect Immun (2012) 80(12):4167-76. doi:10.1128/IAI.00417-12

68. Shourian M, Flaczyk A, Angers I, Mindt BC, Fritz JH, Qureshi ST. The Cnes2 locus on mouse chromosome 17 regulates host defense against cryptococcal infection through pleiotropic effects on host immunity. Infect Immun (2015) 83(12):4541-54. doi:10.1128/IAI.00697-15

69. Zhang Y, Wang F, Bhan U, Huffnagle GB, Toews GB, Standiford TJ, et al. TLR9 signaling is required for generation of the adaptive immune protection in Cryptococcus neoformans-infected lungs. Am J Pathol (2010) 177(2):754-65. doi:10.2353/ajpath.2010.091104

70. Zaragoza O, Alvarez M, Telzak A, Rivera J, Casadevall A. The relative susceptibility of mouse strains to pulmonary Cryptococcus neoformans infection is associated with pleiotropic differences in the immune response. Infect Immun (2007) 75(6):2729-39. doi:10.1128/IAI.00094-07

71. Blasi E, Barluzzi R, Mazzolla R, Pitzurra L, Puliti M, Saleppico S, et al. Biomolecular events involved in anticryptococcal resistance in the brain. Infect Immun (1995) 63(4):1218-22.

72. Maffei CM, Mirels LF, Sobel RA, Clemons KV, Stevens DA. Cytokine and inducible nitric oxide synthase mRNA expression during experimental murine cryptococcal meningoencephalitis. Infect Immun (2004) 72(4): 2338-49. doi:10.1128/IAI.72.4.2338-2349.2004

73. Garlanda C, Dinarello CA, Mantovani A. The interleukin-1 family: back to the future. Immunity (2013) 39(6):1003-18. doi:10.1016/j.immuni.2013.11.010

74. Weber A, Wasiliew P, Kracht M. Interleukin-1 (IL-1) pathway. Sci Signal (2010) 3(105): $\mathrm{cm} 1$. doi:10.1126/scisignal. $3105 \mathrm{~cm} 1$

75. Casanova JL, Abel L, Quintana-Murci L. Human TLRs and IL-1Rs in host defense: natural insights from evolutionary, epidemiological, and clinical genetics. Annu Rev Immunol (2011) 29:447-91. doi:10.1146/annurev-immunol030409-101335

76. O'Neill LA, Dinarello CA. The IL-1 receptor/toll-like receptor superfamily: crucial receptors for inflammation and host defense. Immunol Today (2000) 21(5):206-9. doi:10.1016/S0167-5699(00)01611-X

77. Bethea JR, Gillespie GY, Benveniste EN. Interleukin-1 beta induction of TNF-alpha gene expression: involvement of protein kinase C. J Cell Physiol (1992) 152(2):264-73. doi:10.1002/jcp.1041520207

78. Herring AC, Lee J, McDonald RA, Toews GB, Huffnagle GB. Induction of interleukin-12 and gamma interferon requires tumor necrosis factor alpha for protective T1-cell-mediated immunity to pulmonary Cryptococcus neoformans infection. Infect Immun (2002) 70(6):2959-64. doi:10.1128/ IAI.70.6.2959-2964.2002

79. Dinarello CA. Anti-cytokine therapies in response to systemic infection. J Investig Dermatol Symp Proc (2001) 6(3):244-50. doi:10.1046/j.0022202x.2001.00046.x
80. Saperstein S, Chen L, Oakes D, Pryhuber G, Finkelstein J. IL-1beta augments TNF-alpha-mediated inflammatory responses from lung epithelial cells. J Interferon Cytokine Res (2009) 29(5):273-84. doi:10.1089/jir.2008.0076

81. Kawakami K, Qifeng X, Tohyama M, Qureshi MH, Saito A. Contribution of tumour necrosis factor-alpha (TNF-alpha) in host defence mechanism against Cryptococcus neoformans. Clin Exp Immunol (1996) 106(3):468-74. doi:10.1046/j.1365-2249.1996.d01-870.x

82. Milam JE, Herring-Palmer AC, Pandrangi R, McDonald RA, Huffnagle GB, Toews GB. Modulation of the pulmonary type 2 T-cell response to Cryptococcus neoformans by intratracheal delivery of a tumor necrosis factor alpha-expressing adenoviral vector. Infect Immun (2007) 75(10):4951-8. doi:10.1128/IAI.00176-07

83. Huffnagle GB, Toews GB, Burdick MD, Boyd MB, McAllister KS, McDonald RA, et al. Afferent phase production of TNF-alpha is required for the development of protective T cell immunity to Cryptococcus neoformans. J Immunol (1996) 157(10):4529-36.

84. Xu J, Eastman AJ, Flaczyk A, Neal LM, Zhao G, Carolan J, et al. Disruption of early tumor necrosis factor alpha signaling prevents classical activation of dendritic cells in lung-associated lymph nodes and development of protective immunity against cryptococcal infection. MBio (2016) 7(4):e510-6. doi:10.1128/mBio.00510-16

85. Traynor TR, Kuziel WA, Toews GB, Huffnagle GB. CCR2 expression determines T1 versus T2 polarization during pulmonary Cryptococcus neoformans infection. JImmunol (2000) 164(4):2021-7. doi:10.4049/ jimmunol.164.4.2021

86. Leopold Wager CM, Wormley FL Jr. Is development of a vaccine against Cryptococcus neoformans feasible? PLoS Pathog (2015) 11(6):e1004843. doi:10.1371/journal.ppat.1004843

87. Wozniak KL, Vyas JM, Levitz SM. In vivo role of dendritic cells in a murine model of pulmonary cryptococcosis. Infect Immun (2006) 74(7):3817-24. doi:10.1128/IAI.00317-06

88. Siegemund S, Alber G. Cryptococcus neoformans activates bone marrowderived conventional dendritic cells rather than plasmacytoid dendritic cells and down-regulates macrophages. FEMS Immunol Med Microbiol (2008) 52(3):417-27. doi:10.1111/j.1574-695X.2008.00391.x

89. Syme RM, Spurrell JC, Amankwah EK, Green FH, Mody CH. Primary dendritic cells phagocytose Cryptococcus neoformans via mannose receptors and Fcgamma receptor II for presentation to T lymphocytes. Infect Immun (2002) 70(11):5972-81. doi:10.1128/IAI.70.11.5972-5981.2002

90. Pang IK, Ichinohe T, Iwasaki A. IL-1R signaling in dendritic cells replaces pattern-recognition receptors in promoting $\mathrm{CD} 8(+) \mathrm{T}$ cell responses to influenza A virus. Nat Immunol (2013) 14(3):246-53. doi:10.1038/ni.2514

91. Qiu Y, Zeltzer S, Zhang Y, Wang F, Chen GH, Dayrit J, et al. Early induction of CCL7 downstream of TLR9 signaling promotes the development of robust immunity to cryptococcal infection. J Immunol (2012) 188(8):3940-8. doi:10.4049/jimmunol.1103053

92. Dinarello CA. Immunological and inflammatory functions of the interleukin1 family. Annu Rev Immunol (2009) 27:519-50. doi:10.1146/annurev.immunol. 021908.132612

93. Lee PY, Kumagai Y, Xu Y, Li Y, Barker T, Liu C, et al. IL-1alpha modulates neutrophil recruitment in chronic inflammation induced by hydrocarbon oil. J Immunol (2011) 186(3):1747-54. doi:10.4049/jimmunol.1001328

94. Schmitz N, Kurrer M, Bachmann MF, Kopf M. Interleukin-1 is responsible for acute lung immunopathology but increases survival of respiratory influenza virus infection. J Virol (2005) 79(10):6441-8. doi:10.1128/ JVI.79.10.6441-6448.2005

95. Mascarenhas DP, Pereira MS, Manin GZ, Hori JI, Zamboni DS. Interleukin 1 receptor-driven neutrophil recruitment accounts to MyD88-dependent pulmonary clearance of Legionella pneumophila infection in vivo. J Infect Dis (2015) 211(2):322-30. doi:10.1093/infdis/jiu430

96. Barry KC, Fontana MF, Portman JL, Dugan AS, Vance RE. IL-1alpha signaling initiates the inflammatory response to virulent Legionella pneumophila in vivo. J Immunol (2013) 190(12):6329-39. doi:10.4049/jimmunol.1300100

97. Biondo C, Mancuso G, Midiri A, Signorino G, Domina M, Lanza Cariccio V, et al. Essential role of interleukin-1 signaling in host defenses against group B streptococcus. MBio (2014) 5(5):e1428-1414. doi:10.1128/mBio.01428-14

98. Lee YS, Yang H, Yang JY, Kim Y, Lee SH, Kim JH, et al. Interleukin-1 (IL-1) signaling in intestinal stromal cells controls KC/CXCL1 secretion, which correlates with recruitment of IL-22-secreting neutrophils at early stages 
of Citrobacter rodentium infection. Infect Immun (2015) 83(8):3257-67. doi:10.1128/IAI.00670-15

99. Altmeier S, Toska A, Sparber F, Teijeira A, Halin C, LeibundGut-Landmann S. IL-1 coordinates the neutrophil response to C. albicans in the oral mucosa. PLoS Pathog (2016) 12(9):e1005882. doi:10.1371/journal.ppat.1005882

100. Mantovani A, Cassatella MA, Costantini C, Jaillon S. Neutrophils in the activation and regulation of innate and adaptive immunity. Nat Rev Immunol (2011) 11(8):519-31. doi:10.1038/nri3024

101. Mednick AJ, Feldmesser M, Rivera J, Casadevall A. Neutropenia alters lung cytokine production in mice and reduces their susceptibility to pulmonary cryptococcosis. Eur J Immunol (2003) 33(6):1744-53. doi:10.1002/ eji.200323626

102. Wozniak KL, Kolls JK, Wormley FL Jr. Depletion of neutrophils in a protective model of pulmonary cryptococcosis results in increased IL-17A production by gammadelta T cells. BMC Immunol (2012) 13:65. doi:10.1186/1471-2172-13-65

103. Wiesner DL, Smith KD, Kashem SW, Bohjanen PR, Nielsen K. Different lymphocyte populations direct dichotomous eosinophil or neutrophil responses to pulmonary cryptococcus infection. J Immunol (2017) 198(4):1627-37. doi:10.4049/jimmunol.1600821

104. Daley JM, Thomay AA, Connolly MD, Reichner JS, Albina JE. Use of Ly6Gspecific monoclonal antibody to deplete neutrophils in mice. J Leukoc Biol (2008) 83(1):64-70. doi:10.1189/jlb.0407247

105. Hasenberg A, Hasenberg M, Mann L, Neumann F, Borkenstein L, Stecher M, et al. Catchup: a mouse model for imaging-based tracking and modulation of neutrophil granulocytes. Nat Methods (2015) 12(5):445-52. doi:10.1038/ nmeth. 3322

106. Barquero-Calvo E, Martirosyan A, Ordonez-Rueda D, Arce-Gorvel V, Alfaro-Alarcon A, Lepidi H, et al. Neutrophils exert a suppressive effect on Th1 responses to intracellular pathogen Brucella abortus. PLoS Pathog (2013) 9(2):e1003167. doi:10.1371/journal.ppat.1003167

107. Yang CW, Strong BS, Miller MJ, Unanue ER. Neutrophils influence the level of antigen presentation during the immune response to protein antigens in adjuvants. J Immunol (2010) 185(5):2927-34. doi:10.4049/jimmunol.1001289

108. Eken C, Gasser O, Zenhaeusern G, Oehri I, Hess C, Schifferli JA. Polymorphonuclear neutrophil-derived ectosomes interfere with the maturation of monocyte-derived dendritic cells. J Immunol (2008) 180(2):817-24. doi:10.4049/jimmunol.180.2.817

109. Gasser O, Schifferli JA. Activated polymorphonuclear neutrophils disseminate anti-inflammatory microparticles by ectocytosis. Blood (2004) 104(8):2543-8. doi:10.1182/blood-2004-01-0361

110. Bourke E, Cassetti A, Villa A, Fadlon E, Colotta F, Mantovani A. IL-1 beta scavenging by the type II IL-1 decoy receptor in human neutrophils. J Immunol (2003) 170(12):5999-6005. doi:10.4049/jimmunol.170.12.5999

111. Santarlasci V, Cosmi L, Maggi L, Liotta F, Annunziato F. IL-1 and T helper immune responses. Front Immunol (2013) 4:182. doi:10.3389/fimmu. 2013.00182

112. Chung Y, Chang SH, Martinez GJ, Yang XO, Nurieva R, Kang HS, et al. Critical regulation of early Th17 cell differentiation by interleukin-1 signaling. Immunity (2009) 30(4):576-87. doi:10.1016/j.immuni.2009.02.007

113. Sutton C, Brereton C, Keogh B, Mills KH, Lavelle EC. A crucial role for interleukin (IL)-1 in the induction of IL-17-producing T cells that mediate autoimmune encephalomyelitis. JExp Med (2006) 203(7):1685-91. doi:10.1084/jem.20060285

114. Sims JE, Smith DE. The IL-1 family: regulators of immunity. Nat Rev Immunol (2010) 10(2):89-102. doi:10.1038/nri2691

115. Hung CY, Jimenez-Alzate Mdel P, Gonzalez A, Wuthrich M, Klein BS, Cole GT. Interleukin- 1 receptor but not toll-like receptor 2 is essential for MyD88dependent Th17 immunity to Coccidioides infection. Infect Immun (2014) 82(5):2106-14. doi:10.1128/IAI.01579-13
116. Szymczak WA, Sellers RS, Pirofski LA. IL-23 dampens the allergic response to Cryptococcus neoformans through IL-17-independent and -dependent mechanisms. Am J Pathol (2012) 180(4):1547-59. doi:10.1016/j.ajpath. 2011.12.038

117. Xin L, Li Y, Soong L. Role of interleukin-1beta in activating the CD11c(high) CD45RB-dendritic cell subset and priming Leishmania amazonensis-specific CD4+ T cells in vitro and in vivo. Infect Immun (2007) 75(10):5018-26. doi:10.1128/IAI.00499-07

118. Hunter CA, Chizzonite R, Remington JS. IL-1 beta is required for IL-12 to induce production of IFN-gamma by NK cells. A role for IL-1 beta in the $\mathrm{T}$ cell-independent mechanism of resistance against intracellular pathogens. J Immunol (1995) 155(9):4347-54.

119. Denis M, Ghadirian E. Interleukin-1 is involved in mouse resistance to Mycobacterium avium. Infect Immun (1994) 62(2):457-61.

120. Chen W, Havell EA, Moldawer LL, McIntyre KW, Chizzonite RA, Harmsen AG. Interleukin 1: an important mediator of host resistance against Pneumocystis carinii. J Exp Med (1992) 176(3):713-8. doi:10.1084/ jem.176.3.713

121. Juffermans NP, Florquin S, Camoglio L, Verbon A, Kolk AH, Speelman P, et al. Interleukin-1 signaling is essential for host defense during murine pulmonary tuberculosis. J Infect Dis (2000) 182(3):902-8. doi:10.1086/ 315771

122. Caffrey AK, Lehmann MM, Zickovich JM, Espinosa V, Shepardson KM, Watschke CP, et al. IL-1alpha signaling is critical for leukocyte recruitment after pulmonary Aspergillus fumigatus challenge. PLoS Pathog (2015) 11(1):e1004625. doi:10.1371/journal.ppat.1004625

123. Sainz J, Perez E, Gomez-Lopera S, Jurado M. IL1 gene cluster polymorphisms and its haplotypes may predict the risk to develop invasive pulmonary aspergillosis and modulate C-reactive protein level. J Clin Immunol (2008) 28(5):473-85. doi:10.1007/s10875-008-9197-0

124. Wojtowicz A, Gresnigt MS, Lecompte T, Bibert S, Manuel O, Joosten LA, et al. IL1B and DEFB1 polymorphisms increase susceptibility to invasive mold infection after solid-organ transplantation. J Infect Dis (2015) 211(10):1646-57. doi:10.1093/infdis/jiu636

125. Romani L. Immunity to fungal infections. Nat Rev Immunol (2004) 4(1): 1-23. doi:10.1038/nri1255

126. Mayer-Barber KD, Yan B. Clash of the Cytokine Titans: counter-regulation of interleukin-1 and type I interferon-mediated inflammatory responses. Cell Mol Immunol (2017) 14(1):22-35. doi:10.1038/cmi.2016.25

127. Van't Wout JW, Van der Meer JW, Barza M, Dinarello CA. Protection of neutropenic mice from lethal Candida albicans infection by recombinant interleukin 1. Eur J Immunol (1988) 18(7):1143-6. doi:10.1002/eji.1830180728

128. Vonk AG, Netea MG, van Krieken JH, Iwakura Y, van der Meer JW, Kullberg BJ. Endogenous interleukin (IL)-1 alpha and IL-1 beta are crucial for host defense against disseminated candidiasis. J Infect Dis (2006) 193(10):1419-26. doi: $10.1086 / 503363$

129. Deepe GS Jr, McGuinness M. Interleukin-1 and host control of pulmonary histoplasmosis. J Infect Dis (2006) 194(6):855-64. doi:10.1086/506946

Conflict of Interest Statement: The authors declare that the research was conducted in the absence of any commercial or financial relationships that could be construed as a potential conflict of interest.

Copyright (c) 2018 Shourian, Ralph, Angers, Sheppard and Qureshi. This is an open-access article distributed under the terms of the Creative Commons Attribution License (CC BY). The use, distribution or reproduction in other forums is permitted, provided the original author(s) or licensor are credited and that the original publication in this journal is cited, in accordance with accepted academic practice. No use, distribution or reproduction is permitted which does not comply with these terms. 